\title{
A short episodic history of income distribution in Argentina
}

\author{
Facundo Alvaredo ${ }^{1} \cdot{\text { Guillermo } \text { Cruces }^{2} \cdot \text { Leonardo Gasparini }^{2} \text { (D }}$
}

Received: 8 September 2017/Revised: 15 September 2017/Accepted: 30 September 2017

(C) The Author(s) 2017. This article is an open access publication

\begin{abstract}
In this paper, we use tax and household survey data to assess the history of income distribution in Argentina since the beginning of the 20th century. Until the 1970s, the country experienced a fall in inequality in spite of lower income growth. Since then, inequality has generally increased possibly as a result of largescale shocks such as macroeconomic crises and reform attempts, resulting in a convergence towards traditionally more unequal neighboring countries.
\end{abstract}

Keywords Argentine exceptionalism · Argentine history · Inequality · Redistribution

JEL Classification N16 $\cdot$ D63 $\cdot$ O15 $\cdot$ D31 $\cdot$ D33

\section{Introduction}

This paper studies the evolution of the distribution of income in Argentina over a period of 75 years. Its starting point is the decade of 1930, when the country displayed a rather high level of inequality-above other advanced economies. This high inequality set the stage for the policies of Peron and others, which were justified-in part-as attempts to make Argentina a less unequal nation. We deal with the international conditions, the policies and the macroeconomic performance behind these inequality trends in Argentina over the 20th century. However, any explanation of the dynamics of inequality and growth in Argentina faces strong

$\checkmark$ Leonardo Gasparini

leonardo@depeco.econo.unlp.edu.ar

1 Paris School of Economics, Paris, France

2 CEDLAS-Universidad Nacional de La Plata and CONICET, La Plata, Argentina 
limitations in terms of (1) economic theory, (2) the multitude of simultaneous confounding factors and (3) the quality of the statistical evidence available. Moreover, these limitations are reinforced by the peculiarly complex history of the country. We have adopted here a historical perspective.

The evolution of income and wealth inequality during the process of development has attracted enormous attention in the economics literature. ${ }^{1}$ From a historical perspective, this focus was initially concerned with the functional distribution of income between factors of production. The classical view saw workers, capitalists and landlords as separate classes, receiving wages, profits and rent. Workers were assumed to be at the bottom of the hierarchy, and a fall in their share increased inequality. In logic, there was no necessary reason. Later, the analysis has turned to the concept of personal distribution. Nevertheless, as pointed out in Atkinson (1997) many of the links between income distribution and the functioning of the economy are still missing in the theory: we do not know much about the precise connections between inequality and the macroeconomic variables, and the inter-relationships between economic performance and distribution. Economic theory offers a series of valuable insights, but it is not able today to provide a comprehensive explanation of the observed dynamics of individuals' income and the joint distribution of earned income and capital income, taking simultaneously into consideration supply and demand forces, social norms, public choice issues and government actions. This is certainly not an easy task. Atkinson et al. (2010) recognize that building a link between theory and empirical specification is not straightforward. The Kuznets inverse-U curve is one of the best examples: its popularity far exceeds its empirical support. As indicated by Piketty (2001), Piketty (2003) and Alvaredo and Piketty (2009), Kuznets stressed in his 1955 article the key role played by wars, inflation, recessions, and the rise of progressive taxation, though this is not the part of the explanation that most economists choose to remember. It was only at the end of his presidential address to the 1954 annual meeting of the American Economic Association that he suggested that an additional process (based on the well-known two-sector model) might also have played a role. As he himself put it quite directly, what was at the stake in the 1950s was nothing but "the future prospect of the underdeveloped countries within the orbit of the free world." Thus, the optimistic theory of the inverse- $U$ curve is the product of the cold war, as stressed by Piketty (2006).

Increasingly, multi-sector models have dominated the literature on the analysis of income distribution and growth in Argentina-see for instance the discussion and the model proposed by Galiani and Somaini in this special collection. While not able to satisfy Atkinson, Piketty and Saez's demanding criteria, these simplistic theoretical models try to highlight the salience of Argentina's starting conditions in terms of its comparative advantages in land and agriculture, and the complex political economy implied by the development of a relatively well-educated workforce in this context. These particular conditions set out a complicated political

\footnotetext{
1 There is a longstanding literature on the political economy of inequality along the development process - see Hirschman (1973) for a classic analysis, and Robinson (2010) for a recent discussion of redistributive policies in the Latin American context.
} 


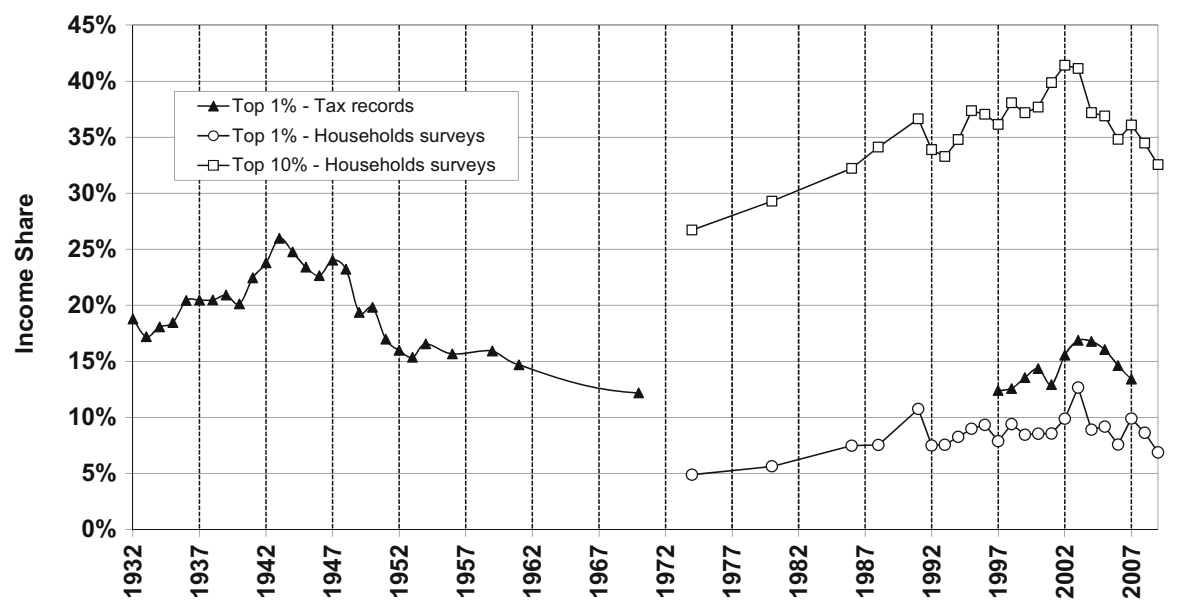

Fig. 1 The top income share in Argentina from tax records (national) and household surveys (Greater Buenos Aires), 1932-2009. Income excludes capital gains Source: Alvaredo (2010), Gasparini and Cruces (2010); The World Top Incomes Database

economy environment whereby distributional conflict drives the alternation between outward and inward-oriented development strategies, with fundamental consequences for long run growth and for inequality itself, both as a determinant and a result of economic policy.

The consequences of this process can be appreciated in the evolution of income and its distribution over time for Argentina. Figure 1 displays the share of the top $1 \%$ of the income distribution between 1932 and 2007 based on personal income tax records, and the share of the top 1 and 10\% from households' surveys between 1974 and 2009. The plot is eloquent of Argentina's distributive performance, with subsequent periods of raising and declining inequality. Figure 2 in turn illustrates

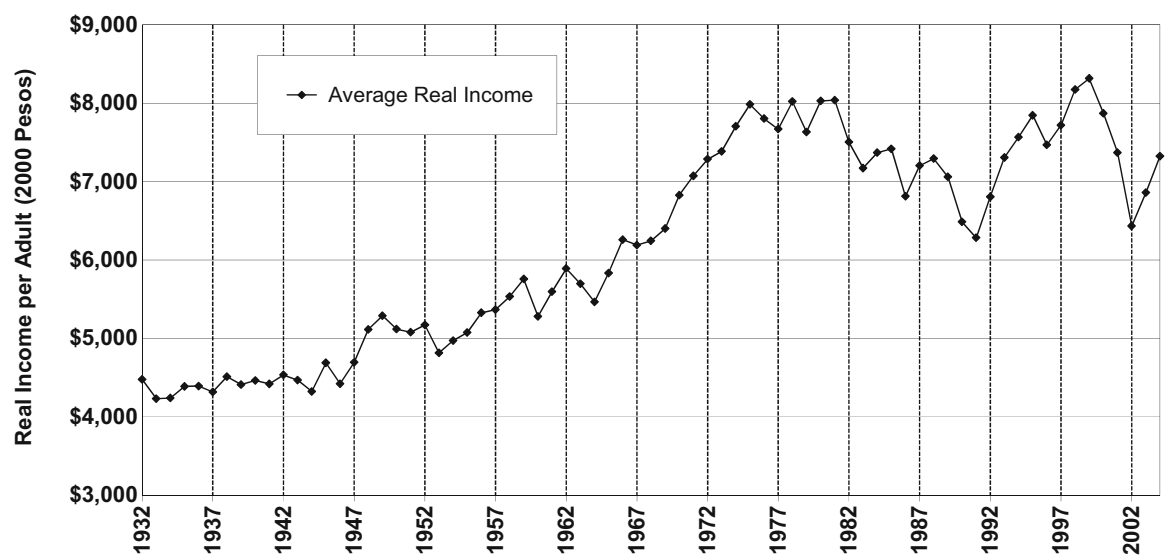

Fig. 2 Average real income and consumer price index in Argentina, 1932-2004. Figure reports the average real income per adult (aged 20 and above), expressed in 2000 Pesos Source: The World Top Incomes Database 
the relative stagnation of real income over the long run, which grew by less than two-thirds over the same period. The combination of both graphs indicates that the interaction between changes in aggregate income levels and in their distribution is a salient feature of Argentina in the 20th century. It should be clear, however, that it is misleading to talk of "trends" when describing the evolution of income inequality. Instead, and along with Atkinson (1997) we follow a much more compelling episodic history of inequality changes in Argentina. The country experienced strong shocks and policy changes that affected the income distribution in different ways. Since the logic behind the inequality changes is different in each episode, a longterm perspective would miss much of the action, and would probably be unhelpful for thinking about the future. Like any other modeling exercise, however, this episodic history tries to highlight the main aspects from a very complex stream of phenomena. Our description and conclusions are, therefore, based on our reading of the events. In some way, the historical narrative is part of the evidence. As (Atkinson et al. 2010) point out, "in combining disparate sets of information, the authors are not carrying out a mechanical operation, but exercising judgement about the strengths and weaknesses of different sources. These narratives are of course subjective, reflecting the standpoints of the authors, and there will no doubt be disagreement about the interpretation of history. But equally they cannot be dismissed."

As described by Della Paolera and Taylor (2001) and many other researchers, Argentina was once a relatively rich country that has consistently diverged from the industrial economies in the last 50 years; today it is indistinguishably a middleincome emerging economy. The deterioration of the country's relative position is often referred to as one of the puzzling cases in the economics of development. It was not a smooth process. The wealth-creating export-based growth model initiated in the second half of the 19th century had its own limitations: high dependency rates, the need on external funding, a large but finite land stock. ${ }^{2}$ Nevertheless, the circumstances helped create an atmosphere of unlimited growth possibilities, which was mutually shared by the ruling class, the people and the immigrants. In contrast, the last 50 years are much more difficult to summarize. While Western countries (including Australia and New Zealand, but also Mexico and Brazil) experienced significant growth after the Second World War, Argentina stagnated and later declined. Political turmoil, institutional instability, macroeconomic volatility, income stagnation, high inflation and two hyperinflations dominated the scenario. Cycles of poor economic performance and continuous political upheavals were associated with the conflict of interests between the landed gentry and the industrialist elite, and with the integration and final acceptance of the working classes into the social and political system. Between 1956 and 2004 real per capita GDP, only grew at an annual rate of less than 1\%; if we consider the figures in the aftermath of the 2001 macroeconomic crisis, the average income did not virtually grew in the 30 years following 1973. By the end of 2002, the unemployment rate was well above 20\%; GDP sunk by $20 \%$ and poverty rates skyrocketed, but

\footnotetext{
${ }^{2}$ For an analysis of these limitations, see Taylor (1992).
} 
recovery resumed rapidly, and the economy grew at annual rates of 7-9\% until 2007.

The academic and non-academic statements about Argentina's performance regarding income distribution, growth and institutions are usually (always?) tainted by ideological preconceptions. We will not offer here a definitive view, but expect to provide the reader with some facts to judge those statements critically, as they need to be qualified. Robinson (2010) sensibly argues that "it is not possible to talk about the market distribution of income as if that were somehow free of politics. It is the political system, after all, that determines the nature of property rights and how free the market is." There is the view that high inequality in the first decades of the twentieth century led to redistributive policies that made the country far more equal but also hurt its economic performance; this view sometimes sees a negative correlation between inequality and growth or, more frequently, it implies that the specific peronist social policies were fundamentally flawed. There are several steps in the argument, and it is unlikely that they will be 1 day uncontroversially settled. It is important to note here that the structural decline of capital concentration that took place between 1914 and 1945 in the developed countries does not seem to have had a negative impact on growth; on the contrary, per capita growth rates were substantially higher in the postwar period (years of the expansion of the welfare state) than in the nineteenth century: high levels of concentration were not a prerequisite for growth.

The remainder of this paper attempts to make sense of these trends in long run income and its distribution by means of an analytical narrative that draws on original empirical evidence and on existing studies of the economic and political factors behind these trends. Section 2 covers the 1932-1973 period and is based mainly on income tax information, while Sect. 3 covers the years 1974-2007 based on household survey data. While the availability of the latter allows for a more detailed analysis at the micro-level, the narratives rely on the same implicit models, which highlight the salience of trade and comparative advantages, the population's level of education and the ensuing distributional conflict and its related redistributive policies. The discussions, thus, cover a series of issues such as trade policy, terms of trade, taxation, technical change, macroeconomic performance, labor regulations, the power of unions and structural reforms.

It is not possible to account for all the complex interactions and phenomena underlying the long period of time in these few pages, and this must be seen as a shortcoming. In this sense, this paper is not addressed to experts in the field, but to a broader general audience. Firstly, we do not analyze in depth almost any of the phenomena mentioned. Secondly, and perhaps most importantly, this review mentions only briefly the political and social forces underlying the trends described here. Hopefully, by concentrating on the evolution of income distribution over time, our analysis complements the efforts regarding these other topics presented in this special collection. Interested readers are also referred to the cited bibliography. The paper is organized as follows. Section 2 focuses on the dynamics of top incomes in Argentina since 1932 based on personal income tax statistics. Section 3 discusses the evolution of income inequality over the last 30 years based on survey data. Section 4 is devoted to the conclusions. 


\section{An episodic history of income concentration in Argentina 1932-1970: evidence from tax statistics ${ }^{3}$}

This section summarizes the dynamics of the concentration of income between 1932 and 1961 based on income tax statistics. ${ }^{4}$ Due to the fact that only a small fraction of the population was subject to the income tax, we can only analyze the very top of the distribution, as depicted in Fig. 1 for the share of the top 1\%. Nevertheless, this source of information is useful for the study of distributive trends, covered in Sects. 2.1-2.3, and also allows for international comparisons, which are described in Sect. 2.4.

\subsection{The years 1932-1945}

In 1929, the Argentine economy-and especially its elite-was suddenly shocked by the Great Depression and the dramatic downturn of conditions in the international markets. The democratic government could not cope with the crisis, and was deposed by the first coup d'état that ended 68 years of constitutional rule. The inability of the elite to understand and adapt to the new situation within constitutional principles, the fear of anarchism and socialism and the necessity to regain political control shaped the following 13 years, 1930-1943, known as the Conservative Restoration and the Infamous Decade. It was a period of electoral fraud, union conflicts and the increasing importance of the army in political affairs. Economic recovery began in 1933 after several years of negative growth. By 1935, GDP had regained the level of 1928. The positive slope displayed by top income shares between 1933 and 1943 (Fig. 1) seems consistent with an increase in concentration during the marked recovery of the economy after the Great Depression. The share of the top percentile rose by 50\% from 1933 to 1943.

Great Britain, the principal destination for exports, abandoned free trade practices and made preferential agreements with the ex-colonies during the Imperial Economic Conference celebrated in Ottawa in 1932 to promote trade within the limits of the empire. Argentina was set aside. The rich landowners pressured for a rapid accord with London to secure the exports to the United Kingdom. The result was the Roca-Runciman agreement, which guaranteed Argentina a fixed share in the British meat market and eliminated tariffs on Argentine cereals. In return, Argentina

\footnotetext{
3 The results presented in this section are taken from Alvaredo (2010).

${ }^{4}$ Our starting point is determined by the source of information: the first personal income tax was established in Argentina in 1932. Income tax data suffer from some serious drawbacks. The definitions of taxable income and tax unit tend to change through time according to the tax laws. While there is a predisposition to under-reporting certain types of income, taxpayers also undertake a variety of avoidance responses, including planning, renaming and retiming of activities to legally reduce the tax liability. Capital incomes and capital gains are taxed at different degrees across time. These elements, which are common to all countries, become critical in developing economies. However, alternative sources such as household surveys are not free from problems regarding under-reporting, differential non-responses, unit design and information at the top of the distribution. Therefore, even if results based on income tax statistics must be read with caution, especially in the case of countries with important levels of tax evasion, they can still be informative and remain a unique source to study the dynamics of income concentration during the first half of the twentieth century.
} 
agreed to restrictions with regard to trade and currency exchange, and preserved Britain's commercial interests in the country. From the macroeconomic point of view, the nature and consequences of this agreement and the true impact on the economic performance are still the topic of academic controversy. There are those who see the treaty as a sell-out to Britain, while others stress that the United Kingdom, by according privileges not given to any other country outside the empire, helped counter the recessionary situation. From the microeconomic side, it may be regarded as a successful mechanism to preserve the elite's (but also the state's) sources of revenue. It must be said, however, that exports more than doubled between 1932 and 1937 almost everywhere in Latin America; Argentina was additionally favored by rising export prices because of droughts in many agricultural competitors. In any case, the Roca-Runciman agreement remains a historical landmark, and the dynamics of top incomes reinforces the idea of the elite's favorable situation during the second half of the decade of 1930.

While top shares started a sustained decrease by the beginning of the Second World War in the developed world (Atkinson and Piketty 2007), they kept growing in Argentina, favored by the export demand from Europe and the evolution of the price of commodities. The country was officially neutral during most of the war for several reasons. On the one hand, a relevant sector of the army showed a clear preference for the Axis. On the other hand, the British interests in Argentina encouraged neutrality, as it ensured the continuation of normal trade with Europe and mainly with the United Kingdom. Great Britain opposed all US proposals of economic sanctions against Argentina, based on the fact that Argentina's neutrality was crucial for ensuring the safe arrival of shipments to British ports. In any case, the elite had been successful again: during the war, $40 \%$ of the British meat and grain markets were supplied by Argentina (Rapoport 1980).

The strong connection between the relatively favorable world market conditions and the evolution of top incomes over this period can be seen in Fig. 3, which displays the total real income reported by the top $1 \%$ and top $0.1 \%$ income recipients along with total agricultural and livestock exports on a logarithmic scale from 1932 to 1956 . The two series are highly correlated and show that when exports increased, high incomes got a larger share of national income, explaining why top incomes followed exports cycles over this period.

\subsection{The years 1946-1955: a great compression}

The Perón years (1943/1946-1955) coincide with a clear decline in the share of the top percentile, which moved down to around $15 \%$ in 1953. Mainly at the expense of rural rents and favored by the accumulation of foreign reserves and the advantageous terms of trade in the world markets after the Second World War and the War of Korea, the Peronist government deepened the industrialization process that had begun many years before, fostered by the impossibility of getting necessary imports from Europe during the war. A deliberate inward-looking policy to finance industrialization and social improvements with rural rents was also to modify the structure of the wealthy sector. New industrial families appeared, but also the old names, traditionally attached to land wealth, diversified to industrial 


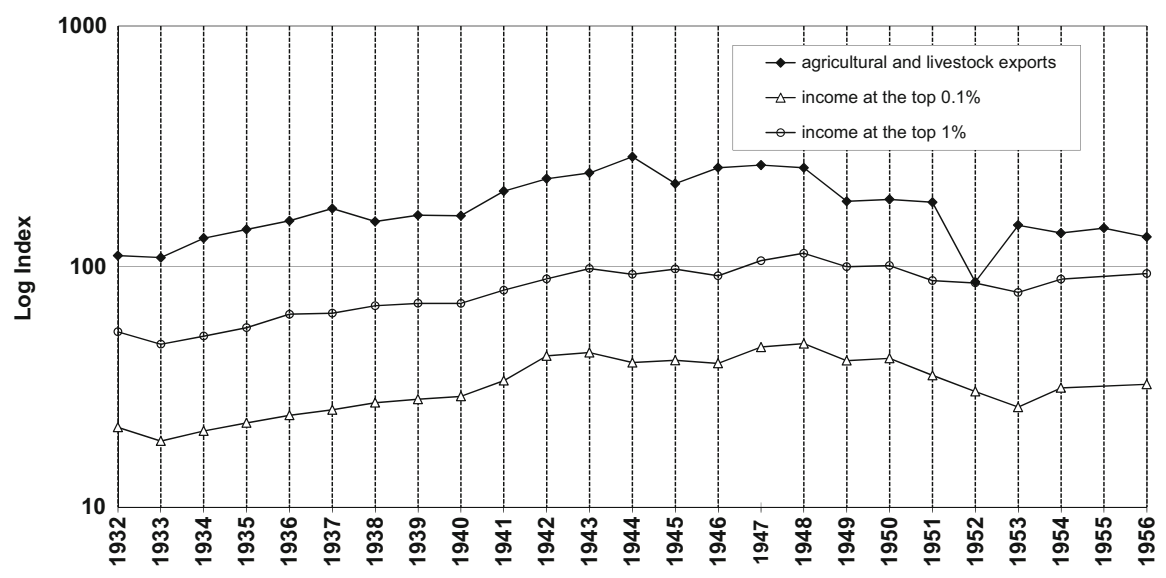

Fig. 3 Agricultural and livestock exports and income at the top, Argentina 1932-1956. Income at the top 1 and $0.1 \%$ is the real amount of income reported by the top 1 and $0.1 \%$ income recipients. The vertical axis measures the logarithm of exports and the logarithm of the top $1 \%$ and the top $0.1 \%$ incomes Sources: Alvaredo (2010) and The World Top Incomes Database for income, and Vazquez Presedo (1998) for exports

production. One important instrument of the Peronist policy was the IAPI, Institute for the Promotion of Trade, which established a state monopoly on exports and limited the gains of large estates proprietors. This State management of exports was a powerful tool in extracting a fraction of the surplus from exporters. The IAPI was disbanded as soon as Perón was deposed in 1955.

Until the beginning of the decade of 1950, the government embarked upon a large redistributive policy and set the grounds for the welfare state and the development of the powerful middle class that characterized the country by the end of decade of 1960. It is this period that remained in the 'collective memory' as the clearest expression of the economic policies of Peronism - the paper by Di Tella and Dubra in this special collection analyzes in a peculiar way these policies and the associated discourse. The development of a progressive personal taxation system played a secondary role, the redistribution being achieved by direct public assistance, subsidized interest rate in the credit markets, price controls, a minimum wage policy, and the state management of exports. Even if income tax rates increased steadily, the number of taxpayers was kept low due to relatively high taxable thresholds. On the eve of Perón's presidency, the top marginal rate doubled, from 12 to $25 \%$ between 1942 and 1943, and was subsequently increased to $27 \%$ in $1946,32 \%$ in 1952 and $40 \%$ by 1955 . Those rates were similar to the levels found in Chile and Brazil, but well below the rates applied to top incomes in developed countries such as France, UK or the United States. ${ }^{5}$

\footnotetext{
5 In the United States, top income tax rates were consistently above 60 percent from 1932 to 1981, and above 90 percent from 1951 to 1963. In the UK, the top marginal tax rates were between 89 and 98 percent between 1940 and 1978. In France, they were equal to or higher than 60 percent from 1941 to 1985 [see Alvaredo et al. (2013), and Piketty and Saez (2013)].
} 
Along with many other transformations, social and labor rights were enforced, unions gained in power, and a generalized national pension system was organized. The Peronist redistributive policy was successful and visible among the working class; this is a widely acknowledged phenomenon. The use of the income tax statistics let us numerically assess the magnitude of the losses experienced by the richest during the Peronist phase. The top percentile share moved down from $25.9 \%$ in 1943 to $15.3 \%$ in 1953 . The most affected seem to have been the richest among the rich: the top $0.1 \%$ decreased from 11.6 to $5.1 \%$ and the top $0.01 \%$ declined from 4.1 to $1.4 \%$ in the same period. The reduction in income concentration was far from trivial, although it had only a limited effect on top incomes by international standards: income concentration in Argentina was still higher than in advanced economies during the same period (see Sect. 2.4 below for an international comparison).

After the frantic expansion of the economy during the years 1946-1949 of Peron's first term, a crisis in the external sector in 1949 forced major changes in the economic policy; initially the expansion of the public sector was held back while attempts were made to retain the policy of increasing wages. A new crisis took place in 1952 (negative trade balance, recession and demonetization). Thereafter, redistribution and credit policies became more prudent and incentives were introduced to favor the agricultural sector (which would always be the main export sector and, as such, the main provider of foreign reserves), which may explain the moderate impact of the drop in exports on top incomes shown in Fig. 3 that year. Some recovery of top shares seems to have started even before the end of Perón's government.

Even if our data do not allow for a detailed explanation of what was happening below the top $1 \%$, the drop in the top shares that took place until the middle of the decade of 1950 coincided with a general improvement in terms of income distribution, as indicated by the fact that the participation of labor in total income in national accounts increased by $8 \%$ between 1945 and 1954 (Altimir and Beccaria 1999). The ratio of labor to GDP reached a historical maximum of $50.8 \%$ in 1954 , 1 year before the military coup that deposed Perón.

\subsection{The years 1956-1970}

After 1955, the intrinsic limits of the import-substitution industrialization strategy (which began to become apparent by the end of Perón's period) resulted in a sequence of oscillating economic policies with deep social and political implications during the following 20 years. Neither the pro-industrialization sector nor the agricultural-based exporter sector (whose interests did not coincide) was powerful enough to permanently dominate the other. There was also the now powerful working class. Repeated cycles of short expansions and contractions, increasing inflation and institutional weakness dominated the period. The model in the Galiani and Somaini's paper in this special collection details some of the political economy mechanisms behind this distributive conflict, whereas the Brambilla, Galiani and Porto's paper describes the oscillation in trade policy over the same period. 
The agrarian activities were responsible of generating the surpluses to foster industry and finance the imports of inputs and capital goods demanded by the expanding manufacturing sector. The exchange rate was usually fixed to help maintain low levels of inflation and high stability of import prices (denominated in local currency). At the same time, extensive and deliberate foreign trade protection secured the industry from external competition even in the face of the appreciation of the exchange rate. As exports were mainly based on food products, any devaluation implied a real loss for wage earners. Consequently, a fixed exchange rate, with a tendency to appreciation, favored both workers and industrialists (protected from external competition) while it acted as a clear disincentive to landowners. The economic tensions translated to the political arena.

Under this scheme, any acceleration of the economy led to fewer exports (more exportable goods were demanded internally) and more imports of inputs and capital goods. Consuming more tradable goods, together with the discouragement of agriculture, generated recurrent balance of payment crises and output contractions. Sometimes the endogenous limits in this development strategy were reinforced by international conditions (drop in world prices of commodities) so that crises also occurred even if the economy was not growing rapidly. The way out of the crisis always implied a tightening of fiscal and monetary policies together with large devaluations that corrected the distortion in prices, favoring land-based activities again, drastically reducing the real value of wages, increasing exports and regaining foreign reserves. Then, the process could restart.

The "stop-and-go" nature of economic policy, which eventually ended by the middle of the 1970s (to inaugurate a decade of stagnation and very high inflation), expressed therefore the limits to industrialization. ${ }^{6}$ It was, nevertheless, a period of reasonable income growth vis-à-vis the poor performance that the economy displayed between 1981 and 1991. ${ }^{7}$ The sudden movements of the nominal exchange rate ultimately led to violent redistributions among workers, the manufacturing sector and the export-oriented agricultural sector. ${ }^{8}$

For this period, we only have observations of top shares for 1958, 1959, 1961, when they show a very small decline, and for 1970, when income concentration seems to be considerably lower than in the 1950s and early 1960s. However, it should be stressed that there is considerable (additional) uncertainty about this last observation. ${ }^{9}$

\footnotetext{
6 For an analytic approach to the 'stop-and-go' model, see Braun and Joy (1967).

7 The political economy and the economic policy of this period have been widely analysed in DiazAlejandro (1970), Mallon and Sourrouille (1975), Di Tella and Dornbusch (1983), Di Tella and Zymelman (1967), Di Tella and Zymelman (1973) among others.

8 The determination of the nominal exchange rate began to play a key and privileged role in all the spheres of the economy. Di Tella (1987) has characterized the styled facts of the pendular policy: a 'repressed stage,' when key prices were controlled to tame inflation, and a 'loosening stage', when controls collapsed and inflation jumped.

9 Tax-based raw data are also available for 1971, 1972 and 1973, but it is difficult to establish their consistency and accuracy.
} 


\subsection{Income concentration in Argentina in international perspective, 1932-1970}

The previous sections discussed the trends in inequality as approximated by the shares of high incomes between 1932 and 1970. Recent work on top income shares allows the comparison of the level and trend of income concentration in Argentina with respect to advanced economies. As discussed in Sect. 1, Argentina was one of the richest countries in the early twentieth century. Figure 4 displays the top 1\% income shares in several economies of 'new settlement,' which are the subject of permanent comparison among scholars when trying to understand and explain the divergence of Argentina. Even if the levels of shares in Argentina, Canada, New Zealand and the United States_-but not in Australia_seem similar in the early 1930s (a commonality which is lost shortly afterwards), it is necessary to stress that several methodological issues limit the comparability of levels across countries (see Atkinson and Piketty 2007): the plot should be read in terms of dynamics and not levels. The same remark applies to Fig. 5, which displays the top $0.1 \%$ income shares in Argentina, France, the United States, Italy, UK, Spain and South Africa. Comparing South Africa and Argentina is particularly interesting: top shares show very similar movements between 1940 and 1960: those were the years of the initial enforcement and development of apartheid in South Africa, which broadly coincide with the accession of Peron to power, as well as with the consequences of his social and economic policies, and with the WWII and the postwar situation. This suggests that the effect of global markets and international conditions affecting world suppliers of raw materials, that is, globalization, also plays a key role in the determination of inequality, which interacts with local economic policies.

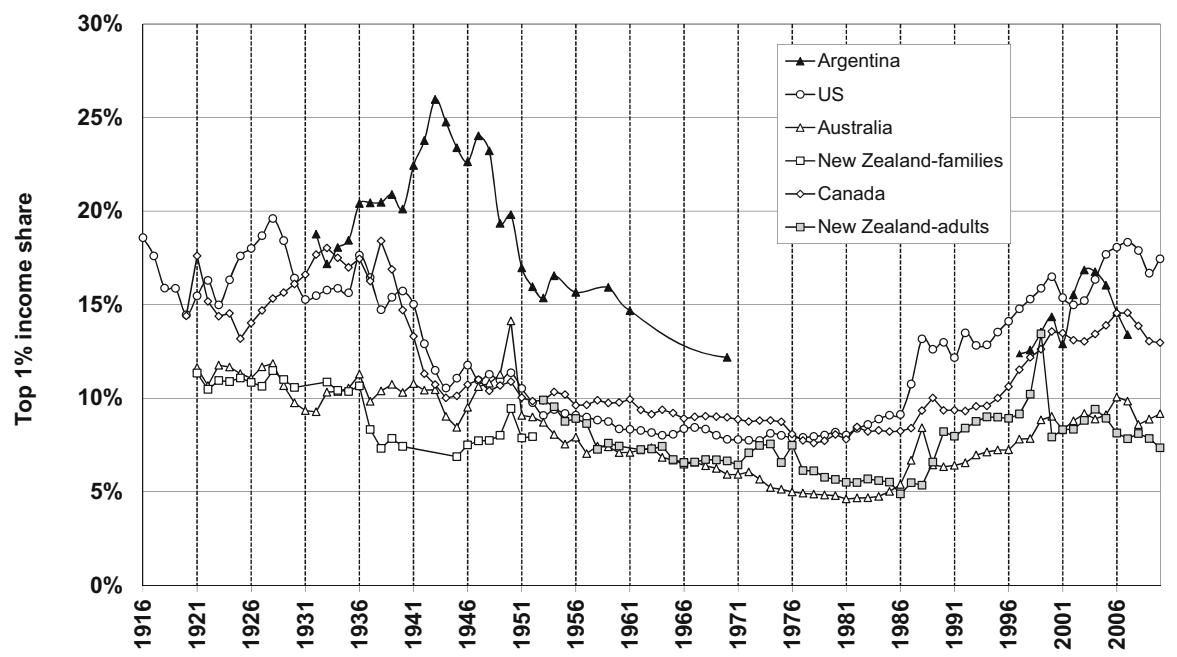

Fig. 4 The top 1\% income share in Argentina, US, Australia, New Zealand and Canada Sources: Argentina: Alvaredo (2010), US: Piketty and Saez (2003), Australia: Atkinson and Leigh (2007); New Zealand: Atkinson and Leigh (2007); Canada: Saez and Veall (2005); and The World Top Incomes Database 


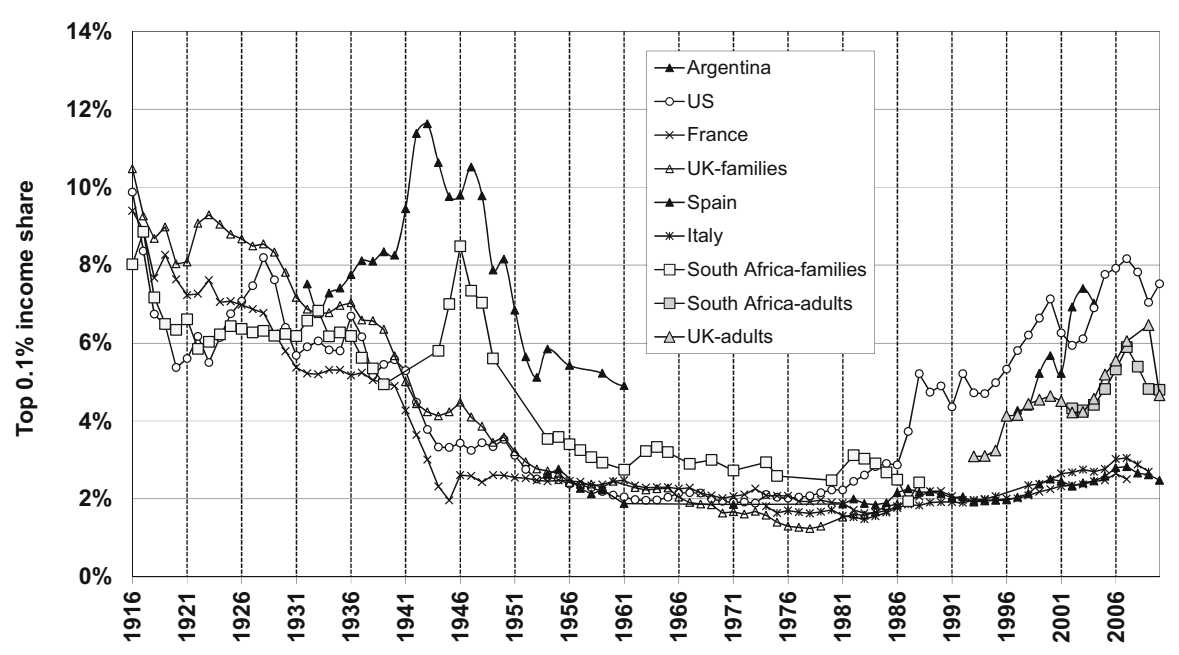

Fig. 5 The top 0.1\% income shares in Argentina, US, France, Spain, Italy, South Africa, and UK Sources: Argentina: Alvaredo (2010); US: Piketty and Saez (2003); France: Piketty (2001) and Landais (2007); UK: Atkinson (2007); Italy: Alvaredo and Pisano (2010); South Africa: Alvaredo and Atkinson (2010) Spain: Alvaredo and Saez (2009); Canada: (Saez and Veall 2005); Australia: Atkinson and Leigh (2007); New Zealand: Atkinson and Leigh (2007); and The World Top Incomes Database. Incomes exclude capital gains

As described in Atkinson and Piketty (2007), the drop in income concentration between 1914 and 1945 in Anglo-Saxon and continental Europe countries was primarily due to the fall in top capital incomes, as capital owners incurred severe shocks from destruction of infrastructure, inflation, bankruptcies and fiscal policy for financing war debts. The reason why capital incomes did not recover during the second half of the century is still an open question; Piketty (2003) and Piketty and Saez (2006) suggest that the introduction of generalized progressive income and estate taxation made such a reversal impossible. For most of the period, the data for Argentina do not offer information about the composition of taxpayers' incomes. This is unfortunate, as economic mechanisms can be very different for the distribution of income from labor, capital, business and rents, and limits the interpretation and comparison of results. In any case, while top shares started a sustained decrease by the beginning of the Second World War in the developed world, they kept growing in Argentina, favored by the export demand from Europe.

The Perón years (1946-1955) coincide with a clear decline in the share of the top percentile, although the evidence also reveals the limited effect on the upper part of the distribution when compared to international standards: by 1954 the top percentile shares were still higher than those found in the United States, France, Canada, Australia or Spain. Here it is worth noticing a striking contrast originated in economic policy between Argentina and Australia. As Atkinson and Leigh (2007) describe, the effect of the commodity price boom after the Second World War directly affected top shares in Australia, generating a clear spike in 1950, mainly due to the peak of wool prices which sheep farmers received in that year. The state management of exports in Argentina seems to have been a powerful tool in extracting a fraction of the surplus from exporters, 
and as a sign of the distributional conflict surrounding trade policy the IAPI was disbanded as soon as Perón was deposed in 1955.

\section{An episodic history of income distribution in Argentina in the late 20th and the early 21st centuries. Evidence from households' surveys}

\subsection{Overall evolution and other data sources}

This section reviews the evolution of income inequality in Argentina between the mid-1970s and the mid-2000s, some of the factors affecting this evolution, and a comparison with other Latin American countries. The empirical evidence relies on information from households' surveys, which are available since 1974.

Over this period, inequality increased substantially, irrespective of the measure employed, but with upward and downward movements. ${ }^{10}$ Figure 6 presents a summary of this evolution by depicting the Gini coefficient for the distribution of household per capita income in the Greater Buenos Aires area (GBA) for years of relative stability. The Gini coefficient soared from 0.345 in $1974-0.483$ in $2006 .{ }^{11}$ The upward trend is statistically significant, as shown in Table 1. It is also robust to the choice of indicator: the share of the poorest quintile declined from 7.2 to $3.7 \%$, the share for the richest quintile rose more than 10 percentage points, from 41.8 to $52.6 \%$, and the 90/10 income ratio increased from around 5 in 1974-11 in 2006. ${ }^{12}$

This change in inequality is also robust to the geographic coverage of the data. Inequality series from 1974 can only be estimated for the Greater Buenos Aires, an urban area containing around a third of Argentina's total population. Notwithstanding this limitation, the trends described in the previous paragraph can be extrapolated to the whole urban population. Figure 7 suggests that inequality estimates for the aggregate of all large urban areas in Argentina (available since 1992) do not differ considerably from those of the GBA. ${ }^{13}$

The trend in inequality can also be inferred from alternative data sources. Using comparable methodologies for the 1985-1986 and 1996-1997 expenditure surveys, Navajas (1999) reports Gini coefficients for the distribution of per capita expenditures of 0.33 and 0.38 , broadly compatible with the trend in income inequality in Fig. 7.

\footnotetext{
${ }^{10}$ This section builds on Gasparini and Cruces (2008) and Gasparini et al. (2011), developed for the thematic Cluster on Poverty, Human Development and MDG's of the Regional Bureau for Latin America and the Caribbean (RBLAC), United Nations Development Programme (UNDP).

11 The microdata behind these figures come from Argentina's main official household survey (Encuesta Permanente de Hogares, EPH), which covers the main urban areas of the country. The EPH started in the $1970 \mathrm{~s}$ as a survey for Greater Buenos Aires (GBA), which accounts for one-third of Argentina's population, and was gradually extended later to cover all urban areas with more than 100,000 inhabitants. As most periodic household surveys in the world, the EPH records labor incomes and cash transfers mainly, but it is weaker in capturing capital income, rents to natural resources and other sources of nonlabor income.

12 Gasparini (2005, Gasparini 2007) also establishes that this trend is robust to a host of methodological issues, including non-response, misreporting of income, inclusion of non-monetary income, inclusion of implicit rent from own housing, accounting for family structure and adjustment for regional prices, among other factors.

13 See Gasparini and Cruces (2008) for more details.
} 


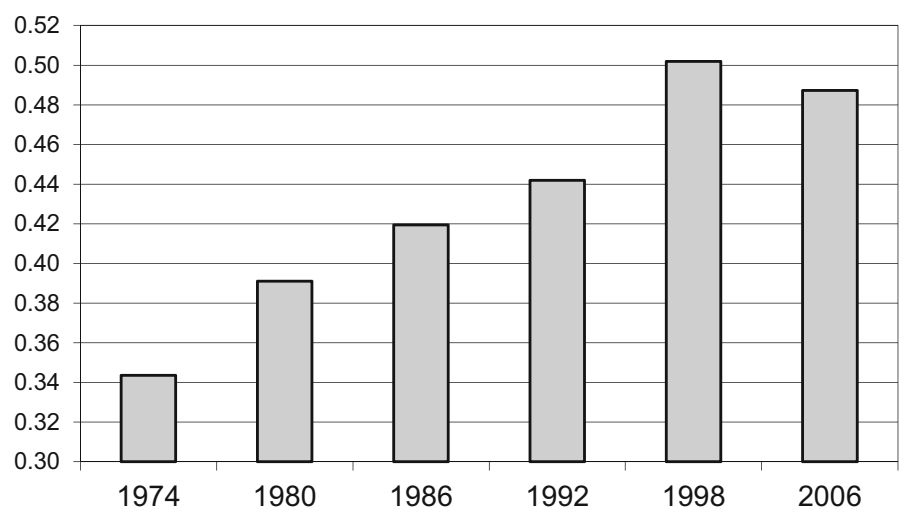

Fig. 6 Inequality in Argentina. Gini coefficient-distribution of household per capita income. Greater Buenos Aires Source: own calculations based on microdata from EPH-INDEC

Galbraith et al. (2006) find a large increase in inequality among formal workers between 1994 and 2002, using microdata from the social security contribution records.

It is also possible to complement indicators based on personal income with the distribution of income between the factors of production, which can be inferred from aggregate national accounts. While the share of wages was around 45 percent in the early 1970s, the estimations for the mid 2000s range from 30 to $38 \%$ (Lindenboim et al. 2005), suggesting again a substantial increase in inequality. ${ }^{14}$

Finally, inequality statistics for the period after 1974 can also be derived from administrative tax sources, as in the previous section of this paper. Figure 1 presented an attempt to reconcile these sources with household survey data-while not strictly comparable, the top income shares from administrative and survey data presented roughly the same trends for the overlapping period available.

The main reference points selected for Fig. 6 depict the evolution of inequality in the long run, but conceal the volatility that characterized Argentina's income distribution along this upward trend. Figure 7 displays the Gini coefficient for all the years for which comparable data are available: there are short periods of relative calm, and episodes of rapid surge in inequality. This volatility contrasts with the relative stability between the mid 1950s and mid 1970s, based on more limited household surveys. A summary of these early indicators is presented in Table 2. The growth-incidence curves in Fig. 8 reflect large and non-neutral income changes. ${ }^{15}$ These income dynamics imply an increase in inequality. Overall, incomes fell over the 1992-2006 period for all centiles of the distribution, but the fall was larger for the poor.

This substantial increase in inequality has strong implications. The poverty headcount ratio in urban Argentina computed with the official moderate poverty line climbed from 18.5 to 26.7 between 1992 and 2006. It is difficult to explain the

\footnotetext{
14 In recent years, an increasing share of wages in aggregated income per se has ceased to be an indicator of diminishing income concentration, since the rise of top wages in English-speaking economies has been a driving force of the sharp increase in top income shares.

15 As in other parts of this section, the discussion focuses on the period 1992-2006 for which data is available for urban Argentina, and not for GBA only, unless it is explicitly mentioned.
} 


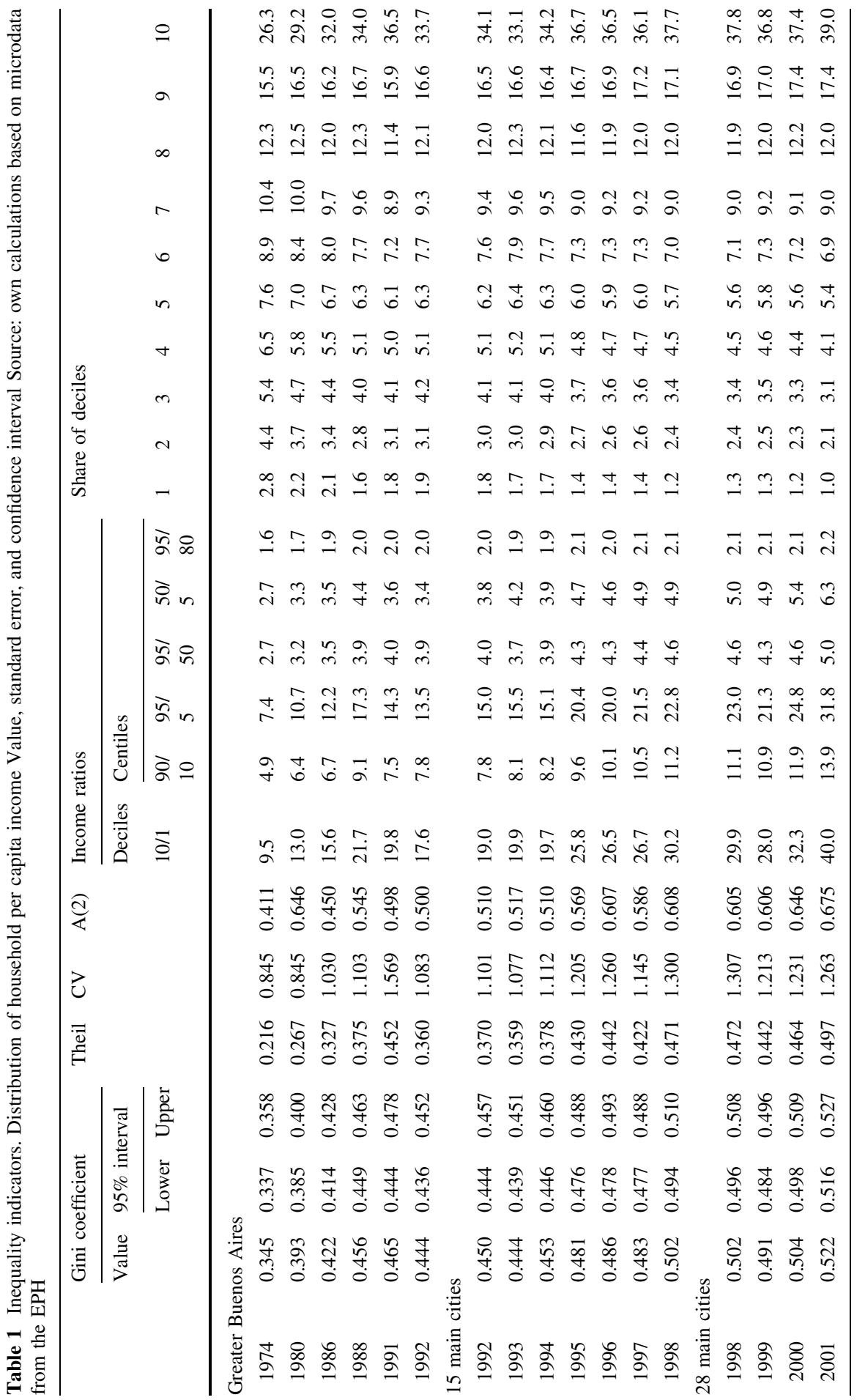




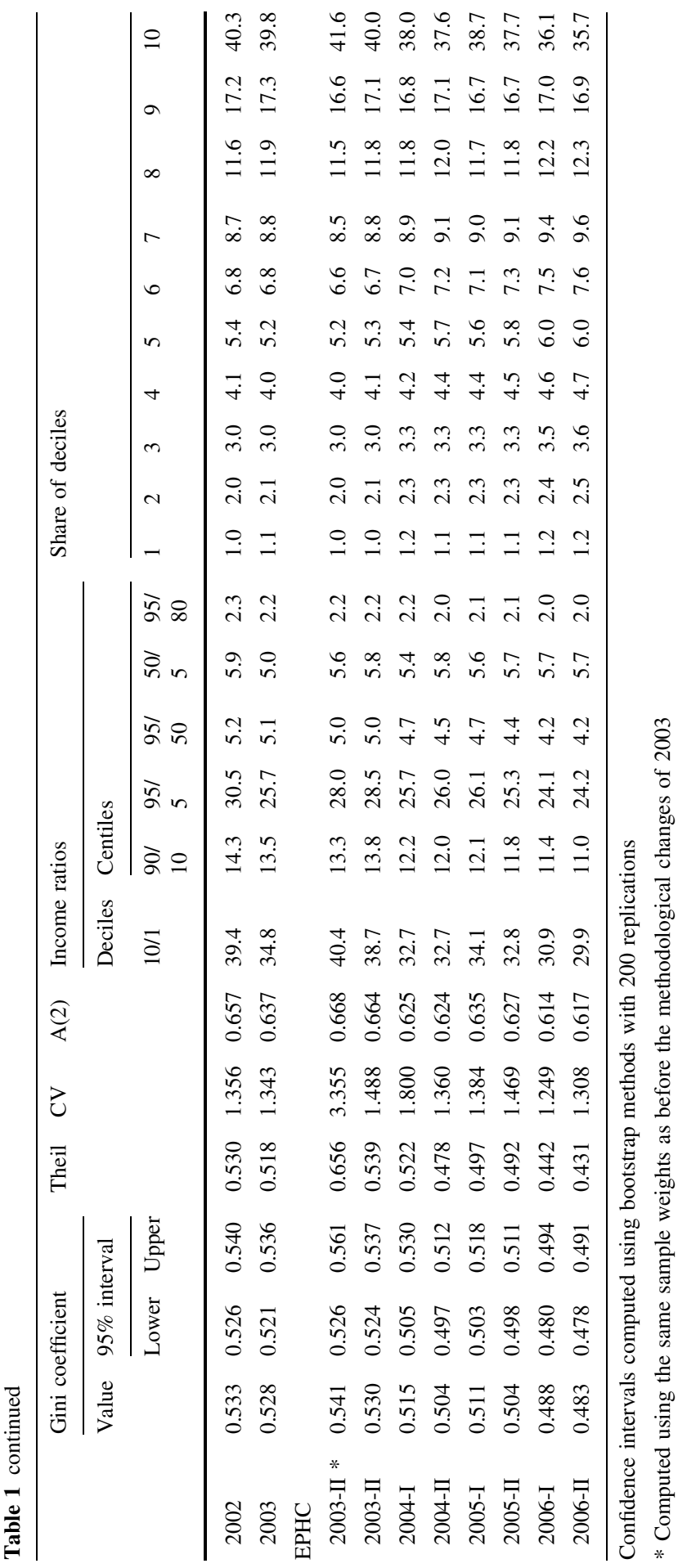

\section{缕 Springer}




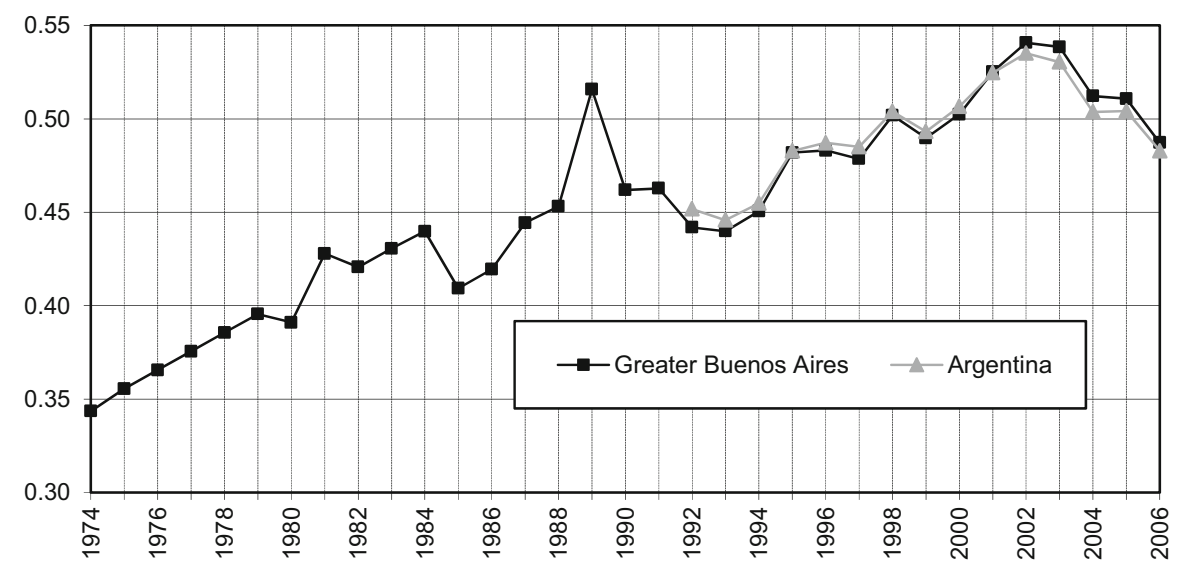

Fig. 7 Inequality. Gini coefficient-distribution of household per capita income. Greater Buenos Aires and urban Argentina Source: own calculations based on microdata from EPH-INDEC

Table 2 Gini Coefficients, 1953-1974 Source: own calculations and Altimir (1986)

\begin{tabular}{|c|c|c|c|c|}
\hline Year & Source & Reference & Coverage & $\begin{array}{l}\text { Gini coefficient } \\
\text { of total } \\
\text { household } \\
\text { income }\end{array}$ \\
\hline \multirow[t]{2}{*}{1953} & \multirow[t]{2}{*}{ CONADE-CEPAL } & \multirow[t]{2}{*}{ CONADE (1965) } & National & 0.400 \\
\hline & & & Non agricultural & 0.368 \\
\hline \multirow[t]{2}{*}{1961} & \multirow[t]{2}{*}{ CONADE-CEPAL } & \multirow[t]{2}{*}{ CONADE (1965) } & National & 0.419 \\
\hline & & & Non agricultural & 0.407 \\
\hline \multirow[t]{2}{*}{1963} & \multirow[t]{2}{*}{ EPC (Income and expenditure survey) } & \multirow[t]{2}{*}{ Altimir (1986) } & Urban & 0.373 \\
\hline & & & GBA & 0.358 \\
\hline $1969 / 70$ & ECIEL (Income and expenditure survey) & Altimir (1986) & GBA & 0.356 \\
\hline 1970 & EED (Labor force and income survey) & Altimir (1986) & GBA & 0.361 \\
\hline 1974 & EPH (Labor force and income survey) & Altimir (1986) & GBA & 0.360 \\
\hline
\end{tabular}

increase in poverty without referring to the worsening in the inequality indicators. The following pages present a narrative of the ups and downs in income inequality in Argentina from the mid-1970s to the mid-2000s.

\subsection{An episodic history of inequality since 1974}

\subsubsection{The first episode: the military regime}

The first episode covers the period from 1974 to the early 1980s, encompassing the last 2 years of a democratic government and the whole dictatorial military regime. ${ }^{16}$

\footnotetext{
${ }^{16}$ Even when the first episode should start in 1976, information from the EPH is available first for 1974, and then from 1980 onwards. Most of the observed distributional changes are attributed to the developments under the military regime.
} 


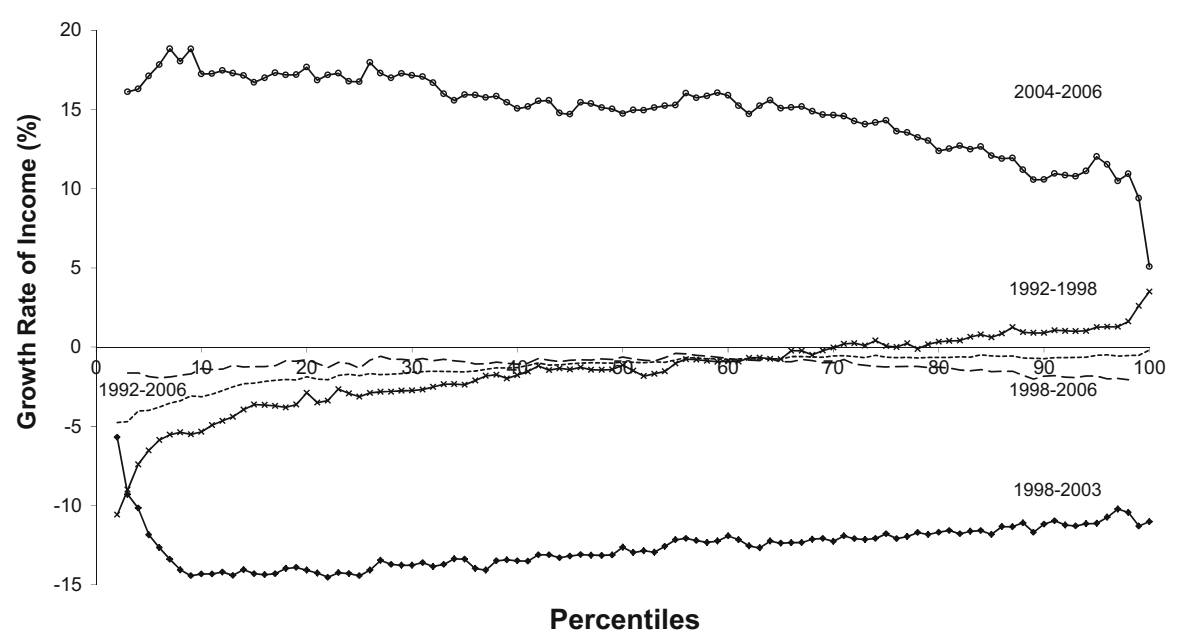

Fig. 8 Growth incidence curves Source: own calculations based on microdata from EPH-INDEC

Weak labor institutions, feeble unions, a sweeping trade liberalization reform, and sharp overall increase in inequality characterize this episode. In March 1976, and by means of a coup d'état, a military regime came into power. The dictatorial government suspended collective bargaining, targeted repression at lower level union leaders, weakened unions, undermined labor institutions, cut down social policies, and initiated a process of trade liberalization. In that framework, income disparities grew substantially: the Gini coefficient for the GBA rose from 0.345 in 1974 to 0.430 in 1981 . Poverty did not increase much, and the economy grew at an annual rate of $1.3 \%$ per capita between 1976 and 1981 .

This episode contains the first of the large macroeconomics crisis that the economy would suffer over the following 30 years. The banking crisis of 1980 and the collapse of the managed exchange rate system in 1981 were followed by a large devaluation and the reversal of capital flows. The situation further deteriorated in 1982, when Mexico's default on its external debt spread through the region. The devaluation of 1981 and the liquidity difficulties of 1982 (fueled by the confidence crisis after the Malvinas war) resulted in a fall of output of around 5\% in 1981 and 1982. The Gini coefficient increased significantly by about $3 \%$ points and poverty rose 2 points from 1980 to 1981 . Although the Gini fell almost one point from 1981 to 1982 , the poverty headcount still increased by $3 \%$ points and rose above the $10 \%$ level. The crisis also determined a substantial closing of the economy (imports fell by $50 \%$ in just 2 years), which marks the beginning of a new episode.

\subsubsection{The second episode: the 1980s}

The second episode comprises most of the decade of 1980, and it is characterized by the return to democratic rule, a substantially more closed economy, increased union activity, stronger labor institutions (minimum wage enforcement, collective bargaining), macroeconomic instability, and a rather stable income distribution. 
The economy remained rather closed from trade, financial markets and technological change, even after democratic rule was restored at the end of 1983. Labor institutions were re-instated, unions regained their power, and social spending increased, although cash transfers remained low. In this scenario, inequality remained stable but poverty increased.

The poor macroeconomic performance over this episode is marked by the fact that capita GDP did not grow between 1982 and 1987, and inflation remained high. This episode is also characterized by the 1985 recession and the ensuing of the Austral stabilization plan. Output fell by $9 \%$ and poverty increased $2 \%$ points in 1985; however, inequality as measured by the Gini coefficient fell by three points with respect to 1984 . The 1985 stabilization plan initially managed to reduce inflation, but it accelerated again in 1986-1988, culminating in two hyperinflation episodes, one in mid 1989 and another in the first quarter of 1990, which mark the following episode.

\subsubsection{The third episode: hyperinflation}

The third episode corresponds to the serious macroeconomic crisis of 1989-1990, which included two bouts of hyperinflation. It is characterized first by a sharp increase and a consecutive sudden fall in inequality after the successful stabilization in 1991. This episode contains the second large increase in income inequality over the whole period under study. Output fell 11\% between 1988 and 1990, and the annual inflation rates were $343 \%$ in $1988,3080 \%$ in 1989 and $2314 \%$ in 1990 .

The hyperinflation crisis had a large distributional impact: poverty increased by $25 \%$ points and the Gini coefficient by 6.3 points between 1988 and 1989, although it should be noted that inequality had been increasing steadily between the 1985 stabilization and the 1989 hyperinflation-induced jump. The Convertibility Plan, which established a currency board, marks the subsequent period.

\subsubsection{The fourth episode: the $90 \mathrm{~s}$}

The fourth episode includes most of the decade of 1990, and it is characterized by relative macroeconomic stability, a currency board with an exchange rate fixed to the US dollar, and deep structural reforms which implied a much more open and flexible economy, with weaker labor institutions. ${ }^{17}$ The income distribution during the 1990s became substantially more unequal.

In April 1991, the country adopted a currency board with a fixed exchange rate regime, the Convertibility plan, which managed to curb inflation successfully: yearly inflation fell from 172\% in 1991 to 25\% in 1992, and from 1993 until 2001 it remained at single digit levels. The Convertibility plan was accompanied by a series of far-reaching structural reforms. The economy grew fast after the implementation

\footnotetext{
17 This stability refers mainly to the curbing of inflation, which was linked to the fixed exchange rate regime (currency board) set in place. The opening of the economy to capital flows implied a high degree of exposure to international fluctuations and to flow reversals, as witnessed by the impact of the succession of crises in Mexico, South-East Asia, Russia and Brazil. See the section on macro crises below for more details.
} 
of the Convertibility plan until 1994, fueled by growing public and private indebtedness from the liquidity in international capital markets. This fourth episode can be identified as a period of trade liberalization, intense capital accumulation and adoption of new technologies, weak labor institutions (lower employment protection, non-binding minimum wages, among others), weak unions, and increasing although still small cash transfer programs. The peronist administration implemented a large set of structural reforms including deregulation, liberalization of trade and of capital markets, privatization of large state-owned enterprises, the demise of a pay-as-you-go pension system in favor of an individual capitalization scheme, and several other market-oriented reforms. In that scenario, the economy started to grow after two decades of stagnation, but inequality went up substantially: the Gini coefficient for urban Argentina rose from 0.450 in 1992 to 0.504 in 2000.

This episode, while more stable in terms of inflation, was not exempt from macroeconomic crises. In December 1994, the newly elected government in Mexico let the currency float, which triggered a capital flight and a financial crisis that severely affected the Argentine economy. The currency board sustained the drain of reserves, but the so-called "Tequila crisis" implied a fall in GDP of around 4\% in 1995. While growth bounced back quickly after the contagion of the Mexican financial crisis, the episode had a very large distributional impact: poverty increased by $5 \%$ points and the Gini index by 2.7 points in a year. The effects of the crisis are also visible in the evolution of the national urban unemployment rate, which soared from $10.7 \%$ in May 1994 to $18.4 \%$ in May 1995. Possibly as a consequence of the reforms, unemployment had already been increasing steadily from $6 \%$ in October 1991 (the first measure before the implementation of the Convertibility plan), but it jumped with the Tequila crisis and remained in double digits until 2007. The crisis also implied a set of changes in the structure of employment, most notably an increase in the labor force participation of women and secondary workers, and the implementation of the Plan Trabajar, a workfare program which would form the basis for future cash transfer initiatives. ${ }^{18}$ Contrary to the previous episode, however, inequality levels and the unemployment rate did not fall during the recovery. It is possible that the financial crisis acted as a catalyst that accelerated and amplified the adverse distributive effects of the ongoing reforms. The Tequila crisis probably exacerbated what was going to be, in any case, a difficult transition to a post-reform economy. While growth resumed over 1996-1998, inequality levels only fell slightly.

\subsubsection{The fifth episode: the recession and the 2001-2002 crisis}

The fifth episode is marked by recession that hit the country in the late 1990s and the ensuing large macroeconomic crisis in 2001-2002, which triggered an economic

\footnotetext{
18 For instance, the participation rate of adult women (aged 25-64) increased from 50.8 to 53.3 percent from 1994 to 1995 , while it remained fairly stable for men in the same age group (91 and 91.3 percent). For the same years, the employment rate for adult women was stable at 45.1 percent, but it decreased from 83.5 to 80.6 percent for adult men, which is reflected in the unemployment rates increases from 11.2 to 15.4 for women and 11.8 to 12.3 for men. The participation rate for adults over 65 also increased throughout the period (CEDLAS, 2011).
} 
meltdown and the devaluation of the currency. This episode is characterized by a sharp increase in inequality.

After the recovery from the Tequila crisis, growth resumed fairly strongly in 1996-1998. Policy inconsistencies (such as electoral spending and debt sustainability issues related to the transition to the fully funded pension system), the exhaustion of the currency board, and an unfavorable international scenario deepened a recession which started in 1999 and triggered a large crisis at the end of 2001. The continuing exposure to international capital flows brought about by the fixed exchange rate regime and the liberalization of the capital account hit the economy at the end of the millennium, with impacts from the 1997 financial crisis in South-East Asia and the 1998 crisis in Russia. In January 1999, the latter resulted in the devaluation of Brazil's currency, Argentina's largest trading partner. The economy entered a period of recession, which culminated in a major economic, banking and financial crisis in December 2001. The currency board finally collapsed after restrictions were imposed on withdrawal of funds from the banks, which triggered a devaluation of the currency. The meltdown resulted in a dramatic fall in output and employment: per capita GDP fell 17\% between 2000 and 2002, and unemployment climbed to $19 \%$.

Over this period, changes in inequality were dominated by the macro situation. The recession and the ensuing crisis had a large impact: the Gini coefficient, for instance, increased 4 percentage points between 1999 and 2002. The most dramatic effect was the combination of the jump in prices (due to the exchange rate pass through) and falling nominal incomes (due to the sharp fall in economic activity), which implied a jump in the official poverty rate from $38.3 \%$ in October 2001 to $53 \%$ in May 2002.

\subsubsection{The sixth episode: the 2003-2007 recovery}

The sixth episode started around 2003 with the rapid growth in the aftermath of the crisis, and lasted until 2008, with the development of a major international financial crisis that globally affected growth, commodity prices, and other relevant factors for Argentina. The average annual growth rate was unprecedentedly high, at $8 \%$ between 2003 and 2007, while the unemployment rate plummeted from almost 20 to $8 \%$. Poverty and inequality indicators fell continuously during the same period. The Gini coefficient reached in 2006 approximately the same level as in the second half of the 1990s, before the start of the 1999-2001 recession.

The strong macroeconomic performance determined the evolution of all socioeconomic indicators during the sixth episode. The fast economic recovery was propitiated by the new structure of relative prices that emerged from the strong devaluation of the peso in 2002: the fall in real wages increased the competitiveness of Argentina's products and deterred imports. New taxes and a default on the government's debt allowed a fiscal surplus that helped stabilize the economy. The social unrest and the political instability of 2001-2002 were curbed by a new and stronger government from the traditional peronist party (2002-2003), with the help of large cash transfer programs displaying rather wide coverage. Moreover, the period saw a large increase in the prices of the commodities exported by the 
country. These exceptional conditions in the international markets were also a key factor in the recovery. The Kirchner administration (2003-2007) did not innovate much from the economic policies inherited from the interim Duhalde's presidency. However, it strengthened labor institutions by supporting the bargaining power of unions and innovating in cash transfer programs.

The main characteristics of this episode include the adjustment of economic agents to the new relative prices implied by the devaluation (and later, depreciation, given that a dirty floating was adopted), stronger labor institutions and a more extensive safety net. Inequality fell rapidly and substantially to pre-crisis levels over this period. Several factors combined to create a scenario where inequality fell over this episode: (1) the stabilization of the economy and the recovery from the crisis 2001-2002; (2) realignments in wages after the devaluation of the peso, (3) a strong employment expansion; (4) lower import competition and productive changes due to the new relative prices, which helped (through the devaluation) unskilled labor intensive industries; (5) slower technical upgrading, due in part to the change in the relative price of imported capital goods; (6) stronger labor institutions, stronger unions and pro-worker labor policies, with increases in the minimum wage and mandated lump sum increases in wages; and (7) a more extensive safety net, with the deployment in 2002 of a large emergency cash transfer program to the poor, which covered up to $20 \%$ of the households in the country.

\subsubsection{A typology of episodes since the late 20th century}

The six proposed episodes can be classified into three types: (1) periods of serious macroeconomic crisis (episodes 3 and 5), (2) periods of liberalization with weak labor institutions (episodes 1 and 4), and (3) episodes of low import penetration and stronger labor institutions (episodes 2 and 6). Inequality seems to have fluctuated widely under type-1 episodes, increased in a rather permanent way under type- 2 episodes, and decreased or remained stable under type- 3 episodes.

\subsection{Determinants of the evolution of inequality}

As the discussion of the episodes highlighted, there are clear differences with respect to the evolution of the income distribution. Figure 9 reproduces the pattern of the Gini coefficient and GDP per capita, and delimits the six episodes. Table 3 in turn characterizes these episodes in terms of five elements: (1) macroeconomic performance, (2) openness to international trade, (2) technological change and physical capital accumulation, (3) unions and labor institutions, and (5) social protection. Changes in the income distribution are the result of a vast array of factors, so any simple classification excludes potentially relevant explanations. The five factors in Table 3 have two elements in common: they have close theoretical links with changes in the income distribution, and they have been extensively invoked in the distributional literature in Argentina. The following pages first describe the stylized facts behind the increase in inequality over the period, and then review the evidence on each of the factors listed in Table 3. 


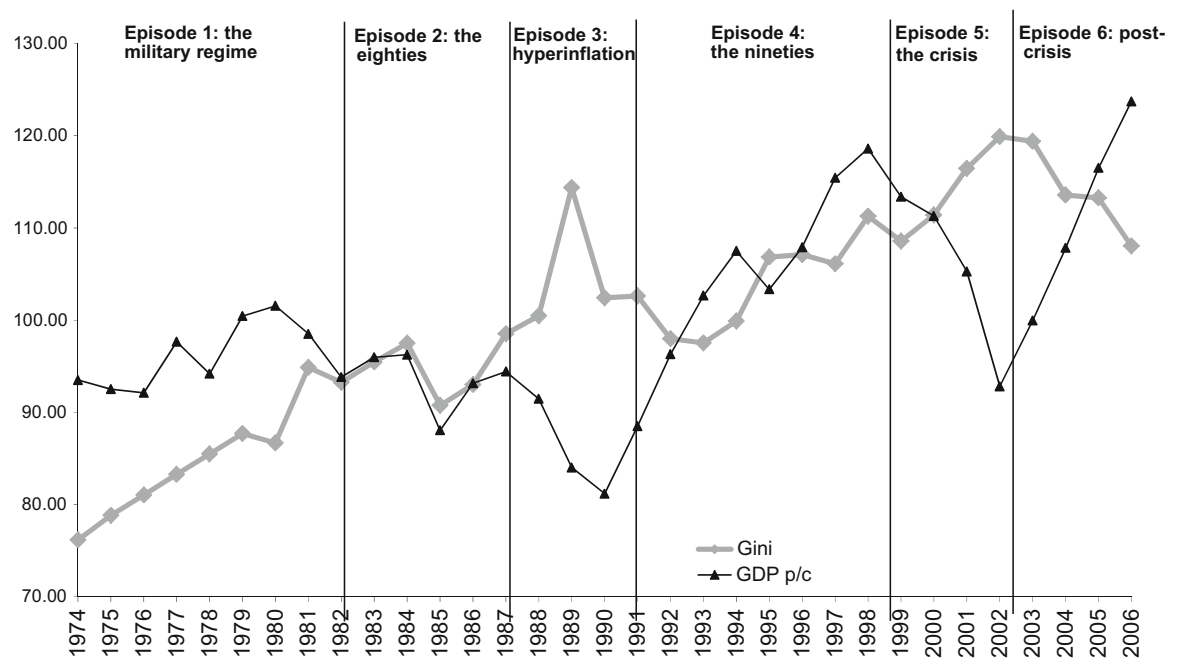

Fig. 9 The six episodes of income inequality in Argentina, 1974-2006 Source: own calculations based on microdata from EPH-INDEC, and National Accounts

\subsubsection{Stylized facts: returns to skills, sectoral changes and supply factors}

The first relevant factor is the evolution of the returns to human capital. Figure 10 illustrates the changes in the returns to education in the context of multivariate wage regressions for the years 1980, 1986, 1992, 1998 and 2006. ${ }^{19}$ These results are based on relatively stable years, to isolate the impact of crises and to focus on the impact of these factors on the trend in inequality. The results in Fig. 10 indicate that the gap between primary school and secondary school graduates did not change much over time. However, the gap between college graduates and the rest fell over the 1980s, but then strongly increased in the 1990s. This is confirmed by Gasparini and Cruces (2008) based on a microsimulation approach, who find that inequality in hourly wages and earnings diminished in the 1980s (ignoring the macro crisis of the late 1980s), driven by a fall in the returns to education in terms of hourly wages. Conversely, during the 1990s the returns to education became highly unequalizing. According to the microsimulation results, the overall effect of returns to education accounts for 4.6 points out of the 8.4 point-increase in the Gini for the equivalized household income distribution. These results suggest that unskilled workers lost in terms of hourly wages and hours of work during the 1990s, and that these changes had a very significant role in shaping the distribution of hourly wages, earnings and household income. The discussion of the determinants of inequality changes below pays particular attention to this phenomenon.

The second stylized fact is the evolution of the relative supply of skilled workers. The simplest explanation for the change in the wage gap between the skilled and the

${ }^{19}$ For an analysis of the earlier part of the 20th century, see the paper by Campante and Glaeser in this special collection, which presents a comparative study of education and returns to skills in Chicago and Buenos Aires. 


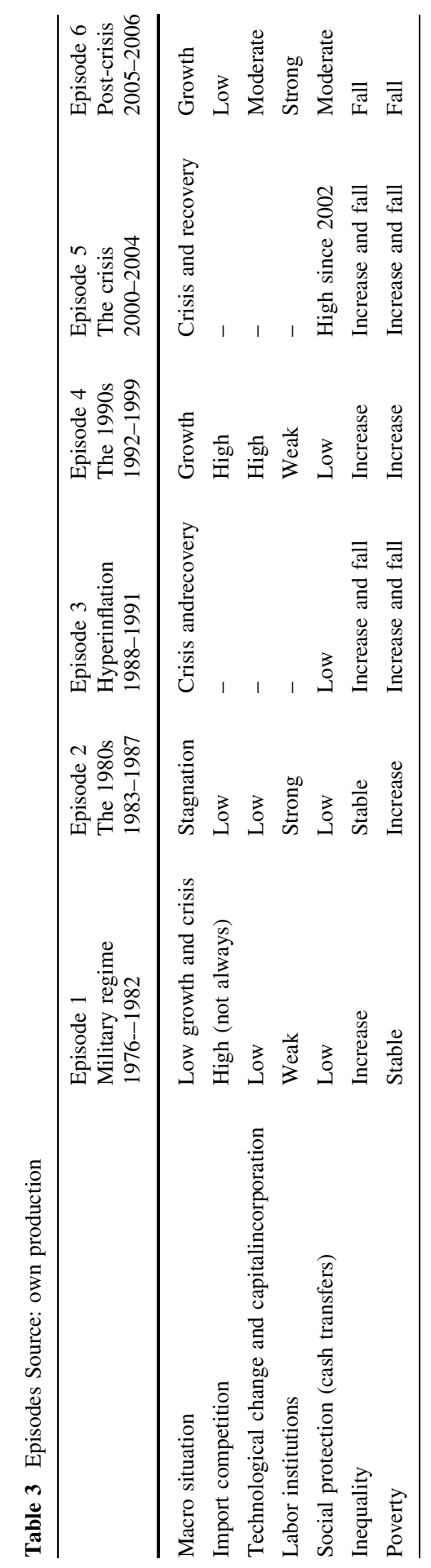



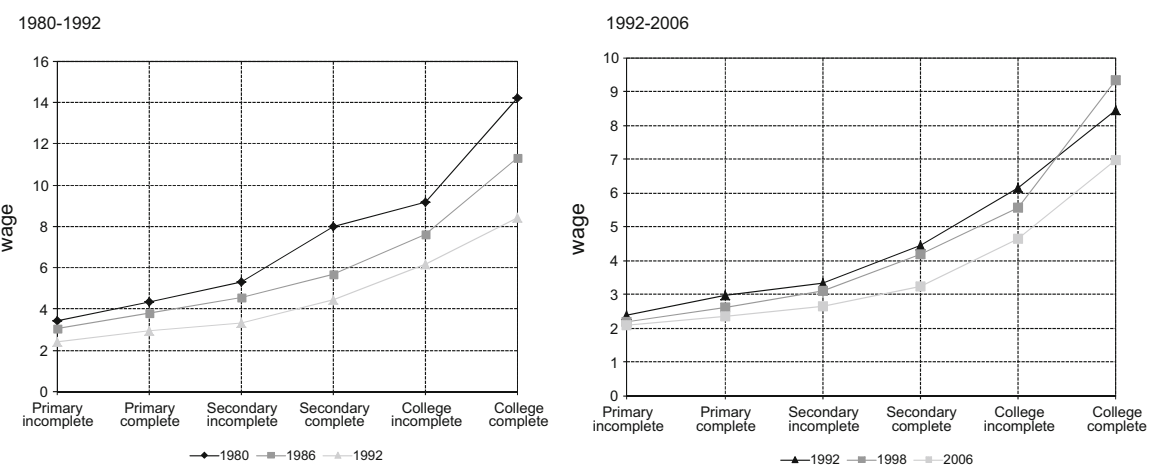

Fig. 10 Returns to education Source: own calculations based on microdata from EPH-INDEC

unskilled relies on changes in the relative supply and demand for both types of workers. Specifically, the skill premium may widen if the relative supply of skilled labor falls. The evidence for Argentina, in fact, reveals a strong increase in the relative supply of semi-skilled (high school graduates) and skilled (college graduates) workers, to the detriment of those with lower levels of skills (those with less than a high school degree). Gasparini and Cruces (2008) show that $78.6 \%$ of adults aged 20-65 were unskilled in GBA in 1974, but that their share fell significantly to $47.1 \%$ in 2006 . For the semi-skilled, the share rose from 17.6 to $37 \%$, and for the skilled from 3.8 to $15.9 \%$. These patterns are even more pronounced when considering the share in employment or in aggregate labor.

The strong increase in the relative supply of college graduates would have driven down the wage skill premium if factor demands had not changed. This appears to have happened in the 1980s, but not in the 1990s. Instead, in the decade of 1990 the college wage premium rose sharply, which suggests an increase in the demand for skilled workers that more than offset the downward pressures from its increased supply.

A third stylized fact refers to the sectoral distribution of workers. Argentina's economy experienced large changes in its productive and employment structure over the period under study. Gasparini and Cruces (2008) discuss the evolution of the shares in aggregate labor by economic sector in Greater Buenos Aires since 1974. The most noticeable change in the labor structure since the 1970s was the fall in employment in the manufacturing industry, and the increase in skilled services (public sector and professional and business services). While in 1974 39\% of employment was in the manufacturing industry, the value dropped to just $17 \%$ in 2006. On the other hand, while in $197421 \%$ of employment was in the more skilledintensive sectors of professional and business services and the government, that share rose to 41 percent in 2006 . These patterns do not vary substantially when dividing the population of workers by skills.

The change in income inequality thus occurred against a backdrop of an increase in the wage skill premium, in the relative supply of skilled workers, and on increased use of skilled labor across economic sectors. The rest of the section reviews the plausible determinants of these observed trends. 


\subsubsection{Macroeconomic factors: hyperinflation, meltdown and adjustment}

The macroeconomic performance of Argentina has been characterized by low growth, and high volatility from the early 1970 s to the mid 2000s. Table 4 provides data on a set of related indicators. The macroeconomic performance is usually associated with the central position of the income distribution, and hence with poverty. In contrast, its links to inequality are not unambiguous or well established in the economic literature, since it is not the case that the benefits from growth (or the costs of recessions) are equally shared along the income distribution. However, in most cases large macroeconomic crisis-in terms of high inflation and output and employment falls-are associated with unequalizing changes, because households in the lower end of the distribution have relatively less access to income smoothing and insurance devices. ${ }^{20}$

The inequality dynamics in periods of economic turbulence are largely governed by the macroeconomic situation (see Table 5). Argentina suffered two large crises from the mid-1970s to the mid-2000s with substantial effects on the income distribution. Figure 9 depicts the sudden and large falls in GDP per capita. While the relationship is not a perfect fit, there seems to be a clear negative correlation between the evolution of GDP and inequality indicators during the episodes of crisis and recovery. This is clearly visible during the crises of episodes 3 and 5 , and the recovery of episode 6 .

Understanding and accounting for crises are relevant, first and foremost because of their large negative effect on household welfare, which has been documented elsewhere. ${ }^{21}$ In terms of their effect on inequality, the following paragraphs concentrate on the mechanisms determining the differential impact of crises along the income distribution, and on the channels through which they can have a permanent effect on its shape.

From the macroeconomy-distribution perspective, the two largest crises (1989-1991 and 2001-2002) represent the most interesting episodes over the period, since they present unusually large falls in GDP and simultaneously large distributional impacts. ${ }^{22}$ Under these two large crises, the evolution of poverty and inequality was dominated by the combination of falling output and sudden increases in prices, although the inflationary processes were fundamentally different in nature during both crises. ${ }^{23}$

\footnotetext{
${ }^{20}$ The 1995 crisis in Mexico seems to be an exception. Székely (2005) reports that inequality actually fell between 1994 and 1996, because the reduction in income over all the population was largest among the richest households.

${ }^{21}$ See for instance the discussion for Latin America and the Caribbean in Lustig (2000) and the comparative discussion of the impact of financial crises in the region and South-East Asia in Fallon and Lucas (2002).

${ }^{22}$ The recession preceding the Austral stabilization plan in 1985 was not associated to large increases in inequality. Also, as stated above, the lasting effects of the Tequila crises cannot be disentangled from those of the host of reforms taking place simultaneously.

${ }^{23}$ The devaluation in early 2002 implied a jump in the price level to accommodate the new relative prices of the economy. The inflation in the 2003-2007 period, although increasing, was moderate when compared to the hyperinflations of 1989 and 1991. It was mostly due to the expansive monetary policy, the growing levels of employment and the adjustment of the real exchange rate to its equilibrium level after the devaluation's overshooting in a context of a dirty floating exchange rate regime. Contrary to the experience of the $1980 \mathrm{~s}$, government financing through the inflationary tax did not seem to be a major force behind the changes in the price index.
} 
Table 4 Main economic indicators Source: World Development Indicators and Ministerio de EconomíaRepública Argentina

\begin{tabular}{lllll}
\hline & GDP growth $(\%)$ & Inflation $(\%)$ & Real Exchange Rate $(2000=100)$ & Unemployment rate $(\%)$ \\
\hline 1976 & -2.0 & 444 & 148.6 & 4.0 \\
1977 & 6.9 & 176 & 167.0 & 2.3 \\
1978 & -4.5 & 176 & 127.3 & 1.9 \\
1979 & 10.2 & 160 & 90.4 & 2.1 \\
1980 & 4.2 & 101 & 71.3 & 2.3 \\
1981 & -5.7 & 104 & 92.1 & 5.0 \\
1982 & -5.0 & 165 & 217.5 & 3.7 \\
1983 & 3.9 & 344 & 205.5 & 3.1 \\
1984 & 2.2 & 627 & 189.5 & 3.6 \\
1985 & -7.6 & 672 & 226.1 & 4.9 \\
1986 & 7.9 & 90 & 189.8 & 4.8 \\
1987 & 2.9 & 131 & 193.6 & 5.2 \\
1988 & -2.6 & 343 & 185.5 & 5.7 \\
1989 & -7.5 & 3080 & 295.8 & 7.0 \\
1990 & -2.4 & 2314 & 148.8 & 6.0 \\
1991 & 12.7 & 172 & 111.6 & 5.3 \\
1992 & 11.9 & 25 & 95.7 & 6.7 \\
1993 & 5.9 & 11 & 89.8 & 9.6 \\
1994 & 5.8 & 4 & 88.4 & 13.1 \\
1995 & -2.8 & 3 & 88.0 & 17.4 \\
1996 & 5.5 & 0 & 90.4 & 18.8 \\
1997 & 8.1 & 1 & 92.1 & 14.3 \\
1998 & 3.9 & 1 & 92.6 & 13.3 \\
1999 & -3.4 & -1 & 95.8 & 14.4 \\
2000 & -0.8 & -1 & 100.0 & 19.7 \\
2001 & -4.4 & -1 & 103.9 & 18.8 \\
2002 & -10.9 & 26 & 257.0 & 13.6 \\
2003 & 8.8 & 13 & 219.4 & \\
2004 & 9.0 & 4 & 217.4 & 2.6 \\
2005 & 9.2 & 10 & 203.6 & 208.3 \\
2006 & 8.0 & 7 & & \\
\hline
\end{tabular}

Given the fiscal origin of most high inflation and hyperinflation bouts (Heymann and Leijonhufvud 1995), it is not surprising that the literature concentrates on the differential incidence of the inflation tax. ${ }^{24}$ Ahumada et al. $(1993,2000)$ have quantified the distributional effects of inflation in Argentina

\footnotetext{
${ }^{24}$ Inflation constitutes by definition a proportional tax on nominal balances, but its effect on the income distribution is neutral only if all households face the same inflation rate, if all households have the same income elasticity in their demand for money, or if they all have access to the same "inflation-protection" technologies. Theoretical models have been developed by Bulir (1998) and Sturzenegger (1997), among others.
} 
Table 5 Macroeconomic crisis changes in output, poverty and inequality Source: own calculations based on National Accounts and EPH

\begin{tabular}{llll}
\hline Crisis & Output $(\%)$ & Changes & \\
\cline { 3 - 4 } & & Poverty $(\%)$ & Inequality \\
\hline 1982 & -5 & 3 & -0.7 \\
1985 & -9 & 2 & -3 \\
1989 & -11 & 25 & 6.3 \\
1995 & -4 & 5 & 2.7 \\
2002 & -17 & 24 & 3.6 \\
\hline
\end{tabular}

from a tax-incidence perspective. Recurring to similar methodologies, both studies estimate monetary demand functions, aggregate inflation tax and seigniorage collection, and re-weight the consumer price index by quintile of the income distribution based on the 1987 Household Expenditure Survey. An interesting finding from Ahumada et al. (2000) is that quintile-specific inflation rates do not differ much. However, the results indicate that inflation tax as a proportion of income was about twice as large for households in the first quintile as for those in the fifth quintile over the 1980-1990 period. The impact of the inflation tax on aggregate inequality indicators was comparatively small for high inflation periods, with increases of about 1-1.5 points of the Gini for 1980-1988 and 1990, but extremely large for the year 1989-the inflation tax would imply an increase of 3.4 points in the Gini coefficient.

The available evidence on the impact of hyperinflation on inequality in Argentina suggests a relatively large regressive (and thus inequality increasing) effect. However, this impact should be short lived, since successful stabilization programs often reduce inflation rates drastically. This seems to be confirmed by the 1991-1993 trend of the Gini coefficient (Fig. 9).

The other major episode of macroeconomic crisis was induced by the implosion of the currency board regime in December 2001 and the subsequent financial and economic meltdown, which was particularly virulent even by Argentine standards. Its impact on income inequality has been widely documented. Using a specific survey implemented by the World Bank in the midst of the crisis (June and July 2002), Fiszbein and Galiani (2003) report that almost half of the households suffered a fall in nominal income; they also observe a change in household roles with respect to the labor market, with higher employment among secondary workers as a strategy to complement the fall in income from unemployed (or working reduced-hours) primary workers. Other coping strategies reflected in the survey include relying on the help of family and friends, reducing consumption of nonbasic goods and switching to cheaper products. As in other crises in Latin America, the extremely high level of unemployment implied that school enrollment did not fall significantly among younger children, and only slightly among those aged $16-18 .^{25}$

\footnotetext{
$\overline{25}$ CEDLAS (2008) reports small but positive increases in enrollment rates between 2001 and 2003 for virtually all age groups, from 3 to 23 .
} 
One key component of the crisis was a large bank deposit freeze and liquidity restriction, which in principle has an ambiguous direct distributional effect. ${ }^{26}$ Halac and Schmukler (2004) find that the probability of having savings was positively and significantly associated with measures of income (Bebczuk 2008 reports similar evidence for other countries in the region). Interestingly, however, the authors also find that, among those with savings, the less educated and those with lower incomes had a larger probability of being affected by the bank deposit freeze, which implies that the measure probably had a positive effect on inequality.

While other aspects of the 2001-2002 episode have been studied [see Gasparini and Cruces (2008), for more details], the available evidence clearly states that the poor in Argentina were more affected by crises than the non-poor. However, most of the inequality-increasing factors tend to dissipate relatively quickly, through the increase in employment and income levels in the recovery periods. In the two episodes of large crisis, inequality first jumped but then fell considerably right after the stabilization. There is a debate on the existence of hysteresis effects on inequality from the crises (Lustig 2000), but there does not seem to be definitive empirical evidence for Argentina. While the Tequila crisis might have had permanent effects on the income distribution, it is likely that this was due to the acceleration of the negative aspects of the underlying reform process. Moreover, any permanent effects of the 2001-2002 crisis are difficult to evaluate, since they are confounded with the strong recovery from 2003 onwards. The argument of a permanent reduction in the stock of general human capital does not seem to apply in the latter case, given the aforementioned evidence on non-falling school enrollment, although other subtler mechanisms might be in place. ${ }^{27}$

Finally, regarding the importance of macroeconomic factors for income distribution beyond episodes of crises, a current of the literature attributes the bulk of the increase in inequality in the 1990s in Argentina to the impact of macroeconomic adjustment and the resulting reduction in the aggregate demand for labor (González and Menéndez 2000; Altimir et al. 2002; Frenkel and Gonzalez Rozada 2002; Damill et al. 2003; Beccaria 2006). However, as argued by Gasparini and Cruces (2008), the direct distributional effect of the increase in unemployment in the 1990s seems to be of second order, as it is mainly accounted for by the raise in labor market participation. ${ }^{28}$ The effects of unemployment and adjustment are not mutually exclusive (and might even be complementary) to explanations based on the impact of trade liberalization and skill-biased technical change.

\footnotetext{
26 While no empirical analysis has attempted to link the two phenomena, it is widely believed that the restrictions on withdrawing cash from banks had a poverty and inequality increasing effect by starving the cash (or informal) economy.

27 While no empirical analysis has attempted to link the two phenomena, it is widely believed that the restrictions on withdrawing cash from banks had a poverty and inequality increasing effect by starving the cash (or informal) economy.

28 The increase in unemployment may have depressed wages for those employed, especially among the unskilled and the semi-skilled, which bore the largest increase in joblessness, and this might have contributed to a higher wage premium and increased inequality, although there is no systematic evidence on the strength of this phenomenon in Argentina.
} 


\subsubsection{Trade liberalization, technical change and capital incorporation: implications for income inequality in the Argentine case}

The relationship between international trade and inequality has long been a key issue in Economics. The degree of openness of a country is a crucial determinant of its price structure, and hence of the structure of employment and factor remunerations. The paper by Galiani and Somaini in this special collection presents a model of these aspects of the Argentine economy during the 20th century, highlighting the political economy factors behind the drives for integration to the world economy. While this model provides the political economy backdrop for the relationship between trade and evolution of inequality discussed in this section, the evidence presented below is partly based on the discussion by Brambilla, Galiani and Porto, also in this special collection. These authors review the history of Argentine trade policy and its relationship with distributional conflict, international conditions and the country's fundamental comparative advantage in agriculture.

In terms of the analytic narrative of this section, the two periods of large increases in inequality in Argentina (besides the large macro crises), episodes 1 and 4, coincide with an explicit pursue of trade liberalization. More import competition might have induced a reduction in the relative demand for industries that were intensive in unskilled labor, and thus increased overall inequality through increasing skill premia.

The conventional wisdom in economic theory is that unskilled labor, the relatively abundant factor in developing economies, would benefit from trade reform and thus inequality would fall, although these reforms usually have more complex effects (Goldberg and Pavcnik 2004, 2007). As a middle-income country, the case for Argentina was not clear-cut ex ante, especially since the country's relative abundance might correspond to natural resources, which are complementary to capital and skilled labor, and not to unskilled labor (Berlinski 1994; Galiani and Porto 2008). The impact of trade liberalization on the distribution of income is ultimately an empirical question.

The evidence for Argentina suggests overwhelmingly that the episodes of trade liberalization led to an increase in inequality. Galiani and Sanguinetti (2003) were among the first to find evidence of an unequalizing effect of the trade reforms of the 1990s. They find that in sectors where import penetration was deeper, the wage gap between skilled and unskilled widened, although this factor can explain only 10 percent of the total change in the wage premium. While most of the studies on trade and inequality have concentrated in specific episodes (the short-lived liberalization of the 1970s in the earlier literature, and the reforms of the 1990s more recently), the study by Galiani and Porto (2008) extends over 1974-2001, spanning five of the six "episodes", with consecutive periods of protection and liberalization (see Fig. 11 for a time series of the average tariff and the average skill premium in their data). The analysis, based on the impact of sectoral tariffs on the wage skill premium, indicates that the level of tariffs has a positive and significant effect on the wages of unskilled labor, no significant effect on semi-skilled (high school graduates) labor, and a negative impact on the returns to higher education. Taken together, this 


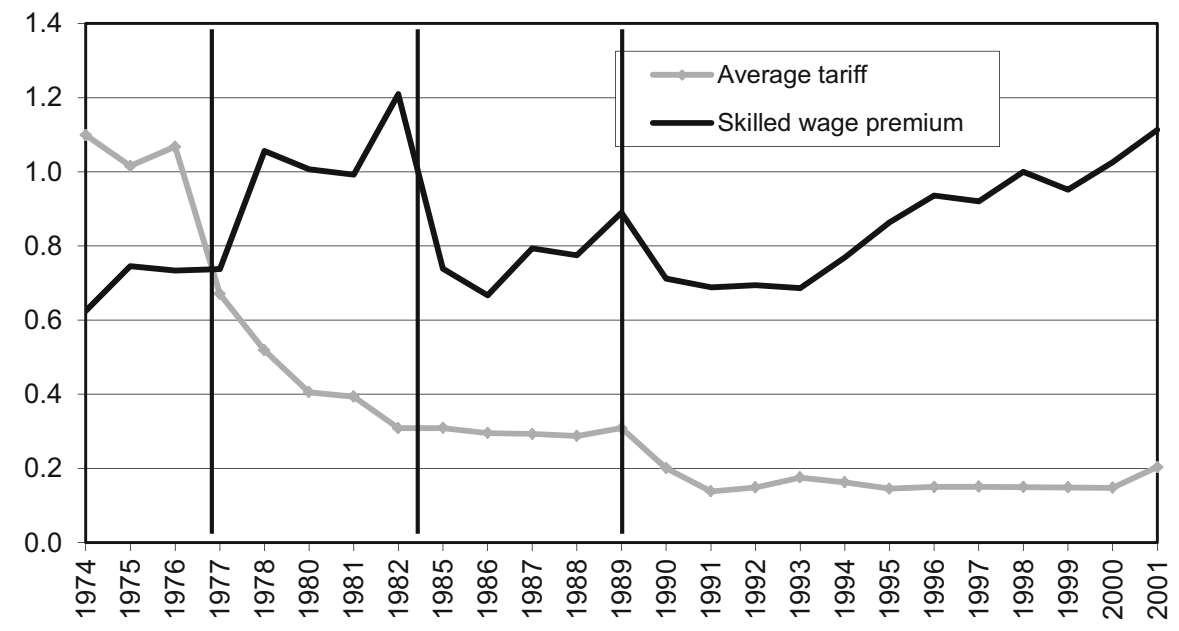

Fig. 11 Trends in tariffs and the wage premium. Author's calculations based on historical trade data and labor surveys (EPH). Tariff: average tariff across all 3-digit ISIC sectors, weighted by employment in each sector. Skilled wage premium: coefficients on the skilled dummy in different earnings regressions per year. See Galiani and Porto (2008); for more details Source: Galiani and Porto (2008)

evidence implies that the trade liberalization episodes increased skill premia and thus contributed to higher overall income inequality in Argentina. ${ }^{29}$

The general conclusion from these and other studies on the distributive impact of trade liberalization in Argentina is that, while more openness implied a wider wage gap and thus higher levels of earnings inequality, its effects can explain a significant fraction of the total increase in the wage premium, but the unexplained part is still large.

The recent literature on income distribution dynamics stresses the importance of technical change and capital incorporation as alternatives (or complements) of the trade liberalization channel. The third factor in Table 3 combines changes in production and organizational technologies, and physical capital accumulation. Both factors are usually associated with a bias towards skilled labor, driving inequality in the labor market. The relevance of this hypothesis for Argentina is confirmed by the evidence linking the large increase in inequality in the 1990s to a shock in the adoption of new technologies, either directly or through its incorporation via capital and international trade.

Some of the plausible concurrent factors behind the large increase in income inequality in Argentina during the decade of 1990 can be derived from the extensions to the standard trade model. Many of the arguments and the evidence point towards the importance of technology and capital accumulation (Goldberg and Pavcnik 2004, 2007). Skill-biased technological change (SBTC), which might arise endogenously from increased trade, and the incorporation of technology through the

\footnotetext{
${ }^{29}$ It must be stressed that, as is the case in all the literature covering the relationship between trade an inequality, the analysis is almost exclusively focused on earnings and not on overall income.
} 
process of capital accumulation might have occurred concurrently to trade reform in Argentina.

The theoretical arguments are relatively straightforward and have been formalized in Krusell et al. (2000), Acemoglu (2002) and (2006). Technological and organizational changes that increase the relative productivity of skilled workers translate into wider wage gaps and, with labor market rigidities, also into lower employment for the unskilled. An increase in the use of physical capital in the production process becomes unequalizing through two channels. First, if capital goods incorporate embedded technological change, an increase in investment in new machinery and equipment can accelerate the adoption of new technologies. Second, even without technical innovations, physical capital is usually more complementary to skilled labor, being then a source of an increasing productivity gap across workers with different education levels. The arguments are compelling, but their empirical relevance for changes in inequality must be established.

Since the mid 1950s and until the mid 1970s, Argentina was a relatively closed economy with low investment rates. The political turmoil of the 1970 s and the stagnant, unstable and protected economy of the 1980s discouraged investment in physical capital, especially foreign investment. A new scenario emerged in the 1990s, combining macroeconomic stability and a set of market-oriented policies, including a massive process of privatizations and deregulations, and measures toward capital account liberalization. On top of that, the real exchange rate appreciation and the large tariff reductions substantially reduced the relative price of physical capital. The favorable international financial conditions also contributed to the massive inflow of foreign capitals. Technology and organizational changes are difficult to measure, and in Argentina they occurred in a period with several policy changes and economic shocks. The evidence in favor of these hypotheses is mostly indirect. Private investment as a proportion of GDP increased strongly between the 1980s and the 1990s. In particular, foreign direct investment as a share of GDP increased from an average of $0.4 \%$ in the period $1970-1990$ to $1.6 \%$ in the period 1991-1997. According to FIEL (2002), the physical capital stock (excluding the public sector) grew by $20 \%$ between 1992 and 1999 . The average age of the capital stock decreased from 8.8 years in 1989 to 5.2 years in 1998. This rapid increase in physical capital, particularly of imported machinery and equipment, was a vehicle for technology modernization after decades of backwardness.

The deregulation of many domestic markets and the removal of barriers to international trade forced private firms to seek the productivity gains necessary to stay in business. Besides, the openness of the Argentine economy occurred just in a moment of increasing globalization and diffusion of new communication and information technologies, inducing firms to adopt state-of-the-art production technologies. Many sectors went through radical changes in their production processes, incorporating information technology, computers, robots and modern assembly lines in just a few years. ${ }^{30}$ These changes also occurred at the organizational level. There was an extraordinary transformation in the property

$\overline{30}$ See Bisang et al. (1996), Kosacoff (1998), Katz (2000) and Bisang and Gómez (2006). 
structure of firms from public to private, from domestic to foreign, and from small to large owners.

Both technological and organizational changes implied a lower relative demand for unskilled and semi-skilled workers. The impact on these workers could have been milder if changes had been adopted gradually, or in a context of strong social protection with compensatory measures. That was not the case: the modernization of Argentina's economy took place in just a few years in a scenario of weak labor institutions, and in the midst of a process of labor deregulation.

A sectoral decomposition of changes in the share of employment by educational groups (Gasparini and Cruces 2008) suggests that the fall in the relative employment of unskilled workers is mainly accounted for by a drop in the intensity of use of this factor within all economic sectors. The "within" effect is particularly relevant in the period 1992-1998, which is consistent with the story of technological/organizational shock in the 1990s. With skilled-biased technological change, the increase in the stock of more educated workers can be easily absorbed in each sector, consistent with a strong increase in the intensity of use of skilled labor in most sectors of the economy. The skill upgrading in production processes was particularly strong in basic and high tech manufacturing sectors, but also in commerce and public administration. Moreover, the observed changes in the returns to education, which favored skilled workers, are also compatible with the SBTC/capital accumulation hypothesis. The returns to observed and unobserved skills substantially increased in the 1990s (and not in the 1980s); a fact that is consistent with a technological shock driving changes in both returns.

Acosta and Gasparini (2007) present evidence of the relationship between capital accumulation and the wage structure by taking advantage of the variability of wage premia and capital investment across industries in Argentina's manufacturing sectors. The results suggest that sectors that accumulated more physical capital in the 1990s were those where the wage premium grew the most. In related work, Bustos (2006) assesses the impact of trade and foreign investment on technology and skill upgrading at the firm level. This study shows that aggregate skill intensity in the manufacturing sector is almost entirely accounted for by skill upgrading within firms. Moreover, the paper shows that firms that upgraded technology faster also upgraded skills faster.

The profound trade and capital account liberalization process of the 1990s was probably a relevant factor in fostering the rapid adoption of new technologies through the capital/technology and trade/technology channels, and these effects might have been larger than the "pure" trade channel covered previously.

The main hypothesis behind the increase in inequality in many developed countries, skill-biased technological change, seems to be present in Argentina. First, changes occurred not only in production technologies, but also in the way of organizing economic activity, including substantial changes in firm size and ownership structure. Second, unlike other countries where changes were introduced gradually, Argentina experienced a shock in the way production was carried out, due to the sudden openness of the economy. Thirdly, the overvaluation of the exchange rate and the global transition towards intensive use of information technologies coincided, driving the adoption of state-of-the-art equipment and 
processes. Finally, as discussed below, changes occurred in a framework of weak labor and social institutions. It should be noted, however, that while several studies suggest the empirical relevance of the argument discussed in this section, there is no conclusive evidence on the overall quantitative importance of this hypothesis.

\subsubsection{Labor institutions}

Labor institutions encompass labor taxation and regulation, freedom of unionization, forms of collective bargaining, minimum wages and other subtler active labor market policies that might reinforce the bargaining power of employees. The literature in general agrees on the equalizing effect of these factors, at least in the short run, although the range of impact estimates is very ample.

The area of labor taxation and regulation was targeted by the first Menem administration in the early 1990s. It introduced a sweeping program of payroll tax reductions, explicitly motivated by the belief that lower taxes would reduce unemployment and promote formalization of the labor market. ${ }^{31}$ The government considered these reductions to be compensatory measures, and thus mandated larger cuts for less developed areas. Cruces et al. 2010, however, report that the reductions had no significant effects on levels of local employment (the purpose of the reform), although the reductions were partially shifted to higher wages. This limited increase in wages implies that the distributional effect should be minor, but with an ambiguous direction: on the one hand, poorer regions received larger cuts, so they should see the largest wage increases (reduction in between region inequality). On the other hand, the cuts only benefited formal workers, potentially increasing within-region inequality.

There has also been some discussion in the literature about the distributive impact of minimum wage levels and their change. The minimum wage was an important variable bargained over by government and unions in the inflationary 1980s because it constituted a centralized device for recouping the erosion of price increases on the purchasing power of wages. In that sense, it is likely that through this channel increases in the minimum wage had an equalizing effect. The low inflation rates in 1993-2001 implied a loss of relevance of the minimum wage, which was fixed in nominal terms at a low level from August 1993 to June 2003, and largely not binding over most of the period. The minimum wage increased substantially from July 2003, coinciding with the recovery of the economy, and it probably had an equalizing effect over the recovery period.

The partial review of the previous paragraphs shows that the distributional impact of labor policies and reform during the 1990s is not a settled issue. Most of the

\footnotetext{
${ }^{31}$ Neffa (2005) provides an exhaustive description of all the changes introduced in this and other aspects of labor regulation in the 1989-2001 period. The Menem administration also introduced a series of socalled "flexible" wage contracts (modalidades promovidas), which allowed firms to legally hire workers with reduced entitlements (such as the reduction or the removal of severance payments for some categories, or rebates in social security contributions), or to make extensive use of trial periods and internships. While these measures certainly implied lower labor standards for registered workers, it is not evident to isolate their distributional impact from the contemporaneous trends in labor markets, marked by increasing unemployment and informality, and from concurrent reforms. Cruces, Galiani and Kidyba (2010) analyze the impact of reductions in payroll taxes on wages and employment.
} 
measures were qualified as anti-labor, and the increase in employment and efficiency that justified them failed to materialize in many cases. However, disentangling the effect of each policy from that of concurrent reforms in the labor market and elsewhere might prove impossible.

The Argentine labor market (and political landscape) has been characterized by the presence of strong, industry wide unions, which played a significant role in shaping the country's social, economic and political outlook, mainly through their relation with the peronist party. Despite the importance of unions in the Argentine economy, there is only limited empirical evidence on their impact on wages and income, mostly because of data availability issues. ${ }^{32}$

There is a broad consensus about the inequality-reducing effects of the first Perón government's pro-labor policies, in which the previous (relatively scattered) unions were centralized and greatly strengthened. ${ }^{33}$ From the 1940 s to the 1950 s union membership increased markedly, from 30 to $51-65 \%$ for manufacturing workers, and from 24 to $38-41 \%$ for non-agricultural workers (Marshall 2005). After this initial consolidation of large unions, it is highly likely that unions also had an overall equalizing effect in the 1950-1970 period, as in more advanced economies. The low levels of informality and high levels of union membership warranted a large fraction of beneficiaries from union activities, and the presence of high tariffs implied a relative abundance of rents to share (and to fight for). Moreover, unions also played an important role in inflationary periods, by helping regain the losses in the purchasing power of wages (which are in fact temporary rents enjoyed by firms).

While consistent series of union membership are not available, the evolution of coverage and strength for 1970-1983 can be deducted from qualitative sources. ${ }^{34}$ In broad terms, unions were only relatively weakened by the authoritarian governments at the beginning of the 1970s, and regained a substantial political and formal power with the return to democratic rule (and to a Peronist government) in 1973. The military coup of 1976 and the ensuing military regime of 1976-1983 implied an important retreat of unions from the labor market, and the persecution of middle and low rank union representatives at the workplace. From 1984 onwards, with the return to democratic rule, it is possible to observe the evolution of union influence from the available data on number of strikes and days lost to industrial action [(figures for 1984-2006 can be constructed from Murillo (1997), and Etchemendy and Collier (2007)]. These figures show a high degree of union activity and volatility during the 1980s, receding greatly from 1991 onwards, and then growing again after 2001. Union membership also declined between 1990 and 2001 (Marshall 2005). These trends are suggestive of a series of factors.

\footnotetext{
32 The EPH, an otherwise fine labor force survey, has never routinely collected information on union membership.

33 The overall distributive effect of unions depends on the characteristics of union members, which is an empirical question. Membership premia might have equalizing effects if members are unskilled, low income workers, while the contrary is also possible if members are mostly skilled or semi-skilled. This is especially relevant in latter periods, with a labor force characterized by higher levels of informal workers.

34 Marshall (2005) presents an informed discussion of the trend in unionization rates in Argentina in the period 1940-2000. The series cannot be presented without this discussion, because the available indicators are not comparable per se; therefore, interested readers are referred to the original article.
} 
The decline in union activity coincides with reforms such as privatizations, trade liberalization and price stabilization of the 1990s, which at least in theory greatly reduced the power of unions. This is due to the dissipation of rents from inefficient state-owned enterprises, from protective tariffs and from the inflation-induced rents and subsequent wage bargaining (Marshall 2002, highlights price stabilization as the loss of a common standard for collective bargaining in this period). The decline in union activity during the 1990s, thus, coincided with a period of rising wage inequality and with factors that according to the evidence reviewed contributed to this rise in wage inequality.

\subsubsection{Cash transfers and poverty reduction programs}

The previous sections analyzed the level and the evolution of inequality from the mid-1970s to the mid-2000s in Argentina, and covered a host of potential determinants of the major changes observed throughout the period. The influence of the state in most explanations was pervasive but indirect, operating mainly through major reforms. Social protection affects income distribution in more straightforward ways. In particular, the impact of cash transfers is directly reflected in income inequality statistics. This section focuses on the direct effect of cash transfer policies and poverty reduction programs. ${ }^{35}$

As described by Gasparini and Cruces (2008), the structure of public social expenditure changed in the period under analysis. The growth in the share of cash transfers from social assistance and emergency employment programs represented the main change, increasing from 15 to $25 \%$. This increase was due to the new workfare programs in the mid 1990s, and to the implementation of a large emergency cash transfer program after the 2001-2002 crisis, the Programa Jefes y Jefas de Hogar Desocupados (PJJHD). The program covered around 2 million households (about 20\% of all households in the country). As the economy recovered, the coverage of the program fell to 1.4 million beneficiaries in $2007 .{ }^{36}$ Gasparini and Cruces (2008) report that the distributional impact of this program has been small, although not negligible-it accounted for a reduction of around 1 Gini percentage point in 2006, and seemed to contrast with the widespread adoption of massive targeted conditional cash transfer programs in the region. However, the economic history of Argentina reviewed in this special collection indicates that groundbreaking policy innovations happen often in the country. In 2009, the Fernandez de Kirchner administration announced the "Asignación Universal por Hijo" program, which expanded the coverage of family allowances to the children of the unemployed and informal workers. The expansion in this benefit's coverage

\footnotetext{
35 Gasparini and Cruces (2008) present a full benefit incidence analysis of taxation and public social expenditure. They find that fiscal policy reduces the level of inequality, but it does not have a significant impact in its evolution over the last decades. This result is driven by the fact that changes in the distributional impact of fiscal policy were small compared to inequality changes driven by "market" forces.

36 The new programs Familias por la Inclusión Social and Seguro de Capacitación y Empleo gained relevance as successors to the PJJHD, but the latter was still the one with the highest number of beneficiaries in 2008. See Cruces and Gasparini (2008) for details on these programs.
} 
resulted in its virtual universalization, and the level of benefits and coverage of the program placed it among the most significant in the region (Gasparini and Cruces 2010).

\subsection{Changes in income inequality in a comparative perspective, 1970s to 2000 s}

The increase in inequality in Argentina from the mid 1970s to the mid 2000s was comparatively large by international standards. This section documents the pattern of income inequality in Argentina with respect to selected Latin American countries. Because of data availability and comparability issues, most of the evidence corresponds to the period 1992-2006.

Although economic historians have conducted research about inequality in socioeconomic indicators in Latin America and the Caribbean from as early as the 15 th century [see Bourguignon and Morrison (2002), Robinson and Sokoloff (2004) and Williamson (2009)], systematic data on the personal income distribution only became available in the 1970s, when several countries in the region introduced household survey programs. However, the early surveys were not implemented at periodic intervals, they were usually restricted to main cities, they collected only limited information about income, and their questionnaires and sampling frames changed over time. This implies that the information available for the 1970s and the 1980s is less comparable than for the latter period [see Altimir (1996), Londoño and Székely (2000) and Gasparini (2003), for reviews of this early evidence].

The literature suggests that in the 1970s inequality fell in several countries-such as Mexico, Bahamas, Panama, Colombia, Peru and Venezuela-and increased in some Southern Cone economies-Argentina, Chile and Uruguay (Gasparini 2003). The weak macroeconomic performance over most of the continent during the 1980s did not help improve the distribution income in most countries. Londoño and Székely (2000) report that the average income ratio of top to bottom quintiles in Latin American countries fell from 22.9 in 1970 to 18.0 in 1982, but rose back to 22.9 by 1991 .

Aggregate trends for the region can be computed since the early 1990s, when most countries in the region consolidated their household survey programs. ${ }^{37}$ Gasparini et al. (2011) report that the mean Gini for the region increased over the 1990s and fell in the first half of the 2000s, with levels in or around 2006 similar to those of the early 1990s. However, they also report that weighting the indices by population changes the whole picture: Brazil and Mexico account jointly for $56 \%$ of the region's population, and experienced stronger equalizing changes than the rest of the countries over the 2000s. The weighted mean of the Gini coefficient is significantly lower in the mid 2000s than in the early 1990s, but although the direction of the overall change in inequality is not ambiguous, the magnitudes are relatively small. The unweighted mean of the Gini first increased and then fell less

\footnotetext{
37 The estimates correspond to selected continental Latin American countries. Information for Caribbean countries is not presented as no country in that sub-region has reliably comparable information available for the early $1990 \mathrm{~s}$. See CEDLAS (2008) for documentation on the coverage of the Socio-Economic Database for Latin America and the Caribbean (SEDLAC), the source of the figures in this section.
} 
than 2 points since the early 1990s, and similar patterns emerge when considering inequality of income for the region as a whole (Gasparini et al. 2011). ${ }^{38}$

\subsubsection{Heterogeneity at the country level}

The overall regional pattern described above, however, masks important differences at the country level. Figure 12 presents the values of the Gini coefficients in the early 1990s and in the mid 2000s for Latin American countries. ${ }^{39}$ Figure 12 suggests a sort of continuum of inequality levels across countries, with values ranging from the low forties up to about sixty Gini points. Uruguay, Venezuela, Argentina and Costa Rica have relatively low inequality levels, while Bolivia, Haiti, Brazil and Colombia are among the most unequal societies in the region. ${ }^{40}$

Latin American countries also differ in the changes of inequality experienced over the period under analysis. Figure 13 presents the changes in inequality (Gini coefficient) for the same countries for the whole early 1990s-mid 2000s period, and for 5 year subperiods. In 7 cases out of 17, inequality did not increase over the 1990s. While the fall in inequality in the 2000s seems more widespread, there are some exceptions. When taking the whole period into consideration, about the same number of countries experienced increases and falls in the Gini coefficients.

\subsubsection{Argentina and neighboring countries}

Figures 14 and 15 depict the Gini coefficients for selected countries in Latin America from 1992 to the mid 2006. As it was apparent in previous figures, the increase in inequality in Argentina is among the largest for the whole period (comparable to that in Costa Rica). The gap with more unequal economies, like Brazil, Mexico or Chile, fell substantially in the last two decades. Income disparities grew during the period of structural reforms of the 1990s, accelerated during the deep macroeconomic crisis of 2001-2002, and fell to pre-crisis levels in the recovery between 2003 and 2006. Neighboring Uruguay, also a country with relatively low levels of inequality, also experienced an increase since the early 1990s, although with a smoother pattern. The Gini coefficient increased by 2 points in the 1990s, grew by around 2 additional points in the stagnation and crisis of the early 2000s, and fell 2 points in the subsequent recovery.

Venezuela has the most egalitarian income distribution in the Andean region. Inequality rose substantially in the $1990 \mathrm{~s}$, with a Gini of 42.5 in 1989 , increasing to

\footnotetext{
38 Regarding sub-regional trends, the changes in inequality were similar in the Andean countries and in the rest of South America: the Gini increased in the 1990s and fell in the 2000s. In contrast, on average the Gini has been slowly falling in Mexico and Central American countries since the early 1990s (Gasparini et al. 2011).

39 Most of the results discussed in this section are robust to inequality indices, income definitions, treatment of zero incomes, and sample variability concerns. The reader is referred to the SEDLAC webpage (www.cedlas.org) for a large set of statistics on these issues.

${ }^{40}$ Even within sub-regions the gaps in inequality levels are large: Southern South America encompasses some of the countries with the lowest (Uruguay) and highest (Brazil) Ginis in LAC; the same is true for the Andean region (Venezuela and Colombia), Central America (El Salvador and Honduras), and the Caribbean (Dominican Republic and Haiti).
} 
Circa 1992

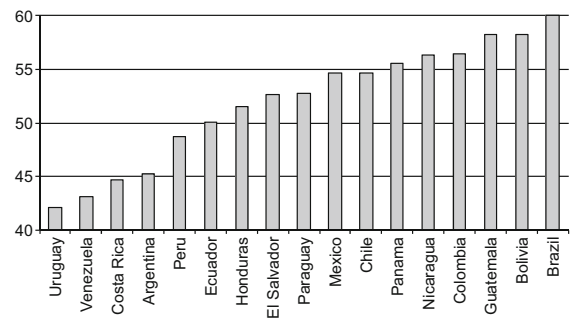

Circa 2006

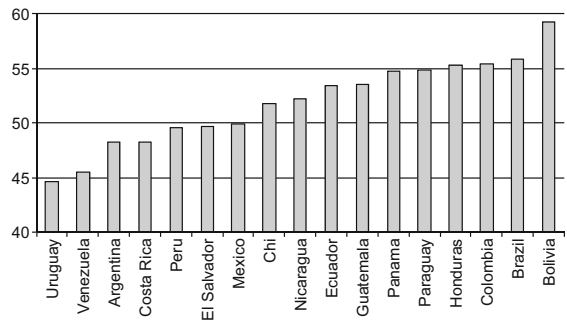

Fig. 12 Inequality in Latin America, 1992 and 2006. Gini coefficients Source: own calculations based on SEDLAC (CEDLAS and The World Bank)

Change Early 1990s-Late 1990s

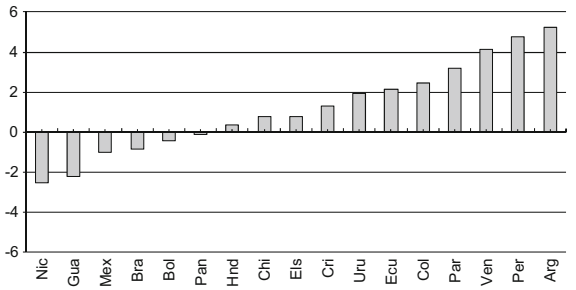

Change Early 2000s-Mid 2000s

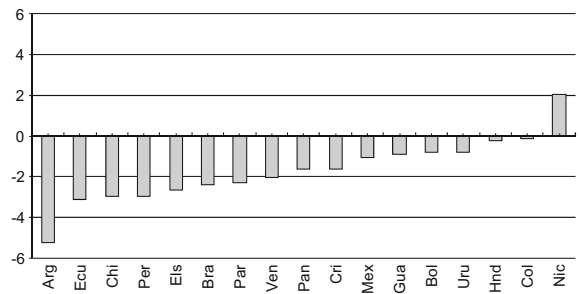

Change Late 1990s-Early 2000s

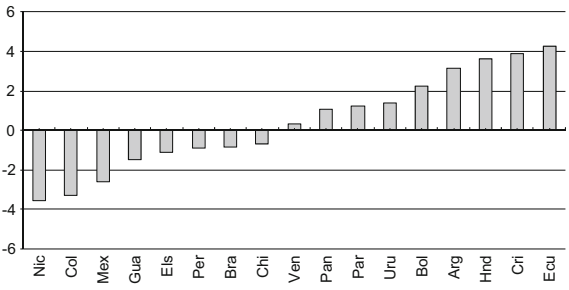

Change Early 1990s-Mid 2000s

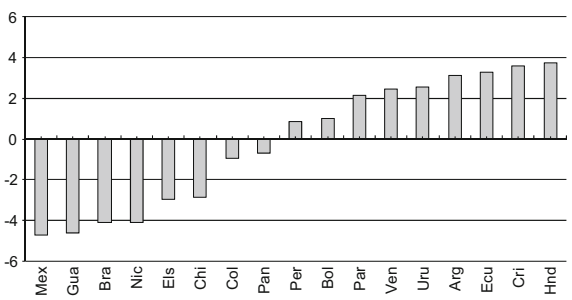

Fig. 13 Change in Gini coefficient. Distribution of household per capita income Source: own calculations based on SEDLAC (CEDLAS and The World Bank)

47.2 in 1998, and fluctuating around that level until 2005. Costa Rica also presents low levels of inequality in a regional perspective, and inequality also increased substantially in the second half of the 1990s. While it has fallen in the 2000s, it has not returned to its previous level: the Gini coefficient for the distribution of household per capita income climbed rose from 44.6 in 1995 to 50.0 in 2001, and fell only to 47.3 in 2005 .

These experiences contrast with those of other countries in the region with high levels of inequality. Brazil has always been one of the most unequal economies in the region. While its income distribution did not change much in the first half of the 1990s, inequality has fallen substantially since 1999; the Gini coefficient was 60.4 in 1990, 58.6 in 1999, and fell to 55.9 in 2006. High levels of inequality have also been a pervasive characteristic of the Chilean economy. However, there are encouraging signs of a significant fall in inequality in the 2000s. The Gini 


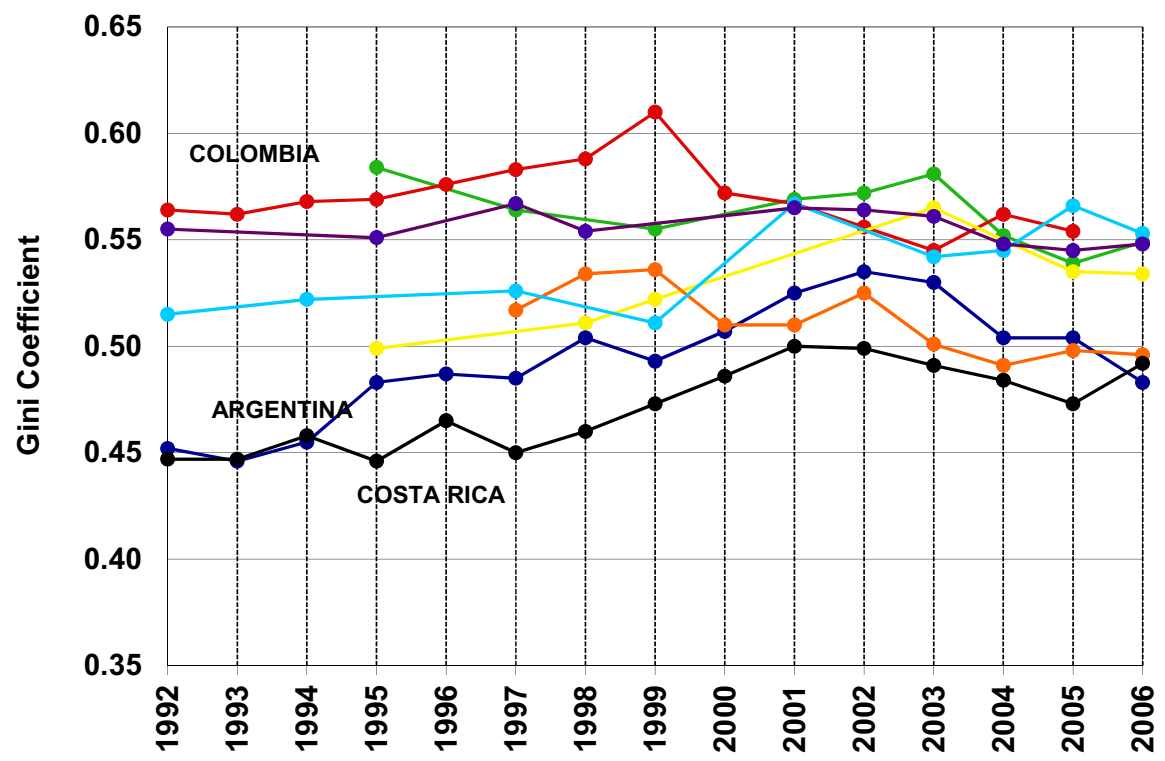

Fig. 14 Gini Coefficients in Latin America 1992-2006. Household per capita income Source: own calculations based on SEDLAC (CEDLAS and The World Bank)

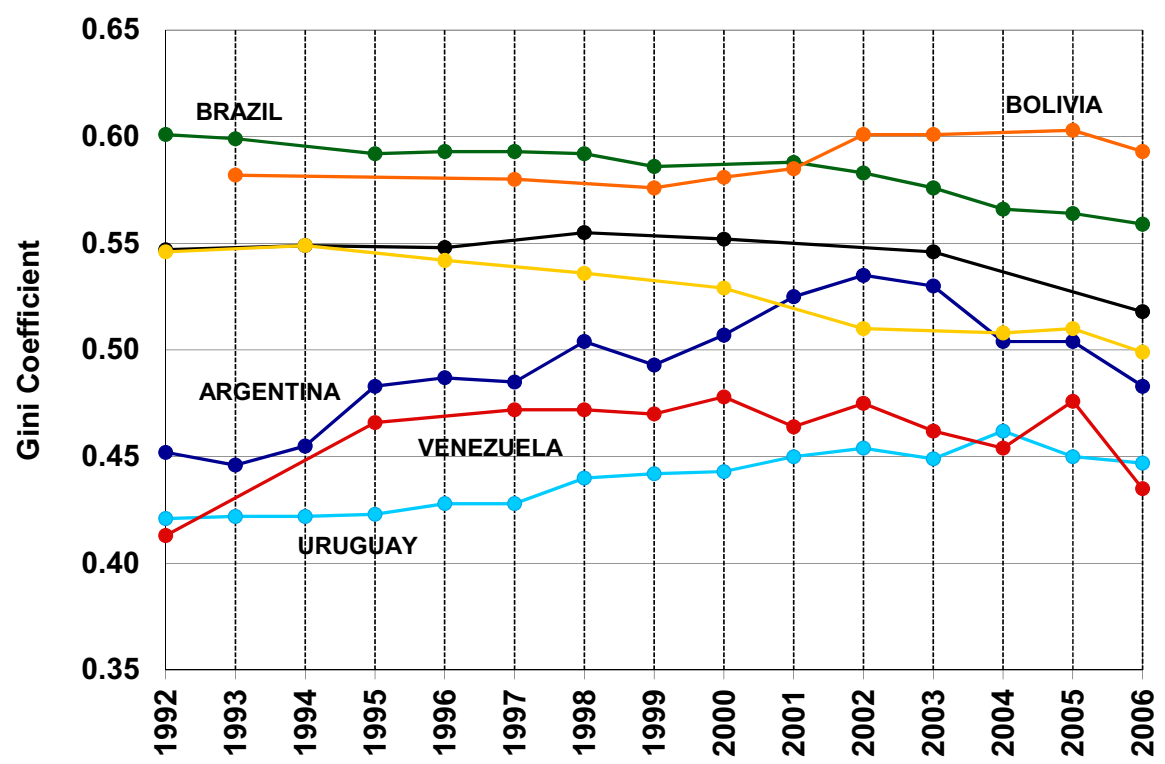

Fig. 15 Gini Coefficients in Latin America 1992-2006. Household per capita income Source: own calculations based on SEDLAC (CEDLAS and The World Bank) 
coefficient, roughly unchanged between 1990 and 2000 (55.1 and 55.2, respectively), fell slightly by 2003 (54.6) and by a larger degree by 2006, reaching 51.8 . Finally, the data for Mexico indicate a slow, although continuous, reduction in income inequality since the early 1990s. The largest fall occurred between 2000 and 2002. The Gini in 2006, at around 50, was almost 5 points lower than in 1992.

\section{Concluding remarks}

This paper described the level and evolution of inequality in Argentina over three quarters of the twentieth century. The evidence for the older period originates in tax returns data, while the figures from the mid-1970s to the mid-2000s are based on household surveys. The review of the trends of inequality and the empirical evidence on its determinants attempted to establish which factors made the Argentine case exceptional-both with respect to other countries in Latin America and to other nations relatively better off at the beginning of the 20th century.

Argentina's level of income started to diverge from that of other rich countries before the middle of the 20th century. The country was also substantially more unequal than others in this selected group, although also relatively more equal than its regional neighbors. The evidence discussed in the previous pages is illustrative of the comparative trends: the gap with traditionally more unequal economies, like Brazil or Chile, substantially shrunk in the last decades of the 20th century. Argentina's income distribution, characterized by a large middle class and large groups with middle and higher educational attainment, was once proudly described as "European" (or more "European" than that of its regional partners, in any case). The average increase in inequality in Argentina has outpaced regional averages with periods of negative growth hitting the poor strongly, while its larger neighbors experienced significant declines: the country seemed to move closer to "Latin American" levels since the early 1990s. Notwithstanding this trend, Argentina's human development index has remained among the highest in Latin America since its publication in 1975, and the post 2002 crisis recovery was accompanied by substantial reductions in inequality-notwithstanding it is too early to judge if this is the beginning of a sustainable downward trend o only a correction of a crisis induced "overshooting".

While not the sole case in the region, both the original low levels of inequality and its upward trend since the mid 1970s are characteristic of the Argentine case. Is there any exceptionality in these developments? The economic determinants of inequality trends discussed in this paper were present in most (if not all) Latin American economies: macroeconomic crises, structural reforms, trade liberalization. However, the strength or scope of these factors seems to be the first exceptional characteristic of the Argentine case. Macroeconomic crises (such as the 2001-2002 collapse and the hyperinflation episodes) were particularly virulent, and the longterm macroeconomic performance (the stagnation in per capita income) is exceptionally disappointing. Moreover, while most countries in the region adopted different aspects of market-oriented reforms, Argentina reformed most aspects of economic life simultaneously, and more deeply and more quickly than its neighbors, 
especially in the 1990s - the only comparable (and earlier) case is that of Chile under a military regime. ${ }^{41}$ The crises and the reforms over the last few decades in Argentina have been deeper and more sudden than in other countries in the region.

Besides the extreme nature of most changes in Argentina, the special characteristics of its social structure also played a role in its large increase in inequality. In the mid 1970s, the Argentine society was characterized by a relatively equal income distribution, and specifically by the presence of a large fraction of workers with middle and high qualifications. The Gini coefficient in those years was not very far from continental Europe countries in 2000. Moreover, according to some authors, the emergence of this publicly educated workforce can be linked to the demand for services by the elite in a land rich economy [see Galiani et al. (2008)]. This modern economy was thus probably more prepared than that of its regional neighbors to incorporate more capital and new technologies, and to absorb the changes brought by market-oriented reforms and liberalization. As discussed at length previously, most of these changes are inequality-increasing, in the short and medium run at least. This apparent convergence with its neighbors might be related to the comparatively higher levels of education in Argentina's population, which resulted in lower initial levels of inequality.

There are, however, other simultaneous factors that have only been partially accounted for in this discussion. Explaining the breadth and speed of crises and reforms, and of the political factors behind them, such as the specificity of the federal structure of the country or of the Peronist coalition, is beyond the scope of this paper. Other papers in this special collection shed some light on the exceptionality of these factors in the Argentine case.

Open Access This article is distributed under the terms of the Creative Commons Attribution 4.0 International License (http://creativecommons.org/licenses/by/4.0/), which permits unrestricted use, distribution, and reproduction in any medium, provided you give appropriate credit to the original author(s) and the source, provide a link to the Creative Commons license, and indicate if changes were made.

\section{References}

Acemoglu D (2002) Technical change, inequality, and the labor market. J Econ Lit 40:7-72

Acosta P, Gasparini L (2007) Capital accumulation, trade liberalization, and rising wage inequality: the case of Argentina. Econ Dev Cult Change 55(4):793-812

Ahumada H, Canavese A, Sanguinetti P, Sosa Escudero W (1993) Efectos distributivos del impuesto inflacionario: una estimación para el caso argentino. Serie Seminarios Instituto T. Di Tella, Buenos Aires

Ahumada H, Canavese A, Gonzalez Alvaredo F (2000) Un Análisis Comparativo del Impacto Distributivo del Impuesto Inflacionario y de Un Impuesto sobre el Consumo. Económica XLVI(2):3-35 (La Plata)

Altimir O (1986) Estimaciones de la distribución del ingreso en la Argentina, 1953-1980. In: 25th Aniversario de Desarrollo Económico. Instituto de Desarrollo Económico Y Social, vol 25, no 100. Buenos Aires, Argentina

Altimir O (1996) Cambios de la desigualdad y la pobreza en la América Latina. El Trimestre Económico 241(LXI): 1

\footnotetext{
${ }^{41}$ On the positive side, Argentina was also the first of the countries in the Southern cone that emerged from authoritarian rule in the 1980s.
} 
Altimir O, Beccaria L (1999) Distribución del Ingreso en la Argentina. Serie Reformas Económicas, CEPAL

Altimir O, Beccaria L, Gonzalez Rozada M (2002) La distribución del ingreso en Argentina, 1974-2000. Revista de la Cepal 78:55-86

Alvaredo F (2010) The rich in Argentina over the XXth century. In: Atkinson A, Piketty T (eds) Top incomes Vol. II: a global view, 6th edn. Oxford University Press, Oxford

Alvaredo F, Saez E (2009) Income and wealth concentration in Spain from a historical and fiscal perspective. J Eur Econ Assoc 7(5):1140-1167

Alvaredo F, Piketty T (2009) The dynamics of income concentration over the twentieth century the case of advanced countries. In: Lopez-Calva L, Lustig N (eds) Markets, the states and the dynamics of inequality, 4th edn. The Brookings Institution, Washington, DC

Alvaredo F, Atkinson AB (2010) Colonial rule, apartheid and natural resources: top incomes in South Africa 1903-2007, CEPR DP 8155

Alvaredo F, Pisano E (2010) Top incomes in Italy 1974-2004. In: Atkinson AB, Piketty T (eds) Top incomes: a global perspective. Oxford University Press, Oxford

Alvaredo F, Atkinson AB, Piketty T, Saez E (2013) The top 1 percent in international and historical perspective. J Econ Perspect 27(3):3-20

Atkinson A (1997) Bringing income distribution in from the cold. Econ J 107:297-321

Atkinson AB (2007) Measuring Top Incomes: Methodological Issues”, in A. Piketty, op. cit, Atkinson and $\mathrm{T}$

Atkinson AB, Leigh A (2007) The distribution of top incomes in australia. Econ Record 83(262):247-261

Atkinson AB, Piketty T (Eds.) (2007) Top incomes over the twentieth century: a contrast between continental european and english-speaking countries. Oxford: Oxford University Press

Atkinson A, Piketty T, Saez E (2010) Top incomes and the long-run history of inequality. In: Atkinson B, Piketty T (eds) Top incomes vol. II: a global view. Oxford University Press, Oxford

Bebczuk R (2008) Financial Inclusion in Latin America and the Caribbean: review and lessons. In: CEDLAS Working Paper N. 68, CEDLAS, UNLP

Beccaria L (2006) Notas sobre la evolución de la distribución de las remuneraciones en la Argentina, Estudios del Trabajo No 32. Asociación Argentina de Especialistas en Estudios del Trabajo, Buenos Aires

Berlinski J (1994) Post Trade Liberalization Institutional Issues in Argentina. Instituto Di Tella Working Paper No 182

Bisang A, Gómez G (2006) Las inversiones en la industria argentina durante los noventa. Serie Reformas Económicas 41, CEPAL, Buenos Aires

Bisang A, Bonvecchi C, Kosacoff B, Ramos A (1996) La transformación industrial en los noventa: un proceso con final abierto. Documento de trabajo 68, CEPAL, Buenos Aires

Bourguignon F, Morrisson C (2002) Inequality among world citizens: 1820-1992. Am Econ Rev 92(4):727-744

Braun O, Joy L (1967) A model of economic stagnation: a case study of the Argentine economy. Econ J 78(312):868-887

Bulir A (1998) Income inequality: does inflation matter? IMF Working paper WP 98/7

Bustos P (2006) Rising Wage inequality in the argentinean manufacturing sector: the impact of trade and foreign investment on technology and skill upgrading. Mimeo, CREI, Barcelona

Card D, DiNardo J (2006) The impact of technological change on low-wage workers: a review. In: Blank RM, Danziger SH, Schoeni RF (eds) Working and poor: how economic and policy changes are affecting low-wage workers. Russell Sage Foundation, New York, pp 113-140

CEDLAS (2008) Socio-economic database for Latin America and the Caribbean (SEDLAC). A joint project between the Centro de Estudios Distributivos, Laborales y Sociales (UNLP) and the World Bank

CONADE (1965) Plan Nacional de Desarrollo 1965-1969. Presidencia de la Nación, Buenos Aires, Argentina

Cruces, G. and Gasparini, L. (2008). "Programas sociales: Integrando a la Población Vulnerable", CEDLAS working paper No. 77

Cruces G, Galiani S, Kidyba S (2010) Payroll Taxes, wages and employment: identification through policy changes in Argentina. Labour Econ 17(4):743-749

Damill M, Frenkel R, Maurizio R (2003) Políticas macroeconómicas y vulnerabilidad social. La Argentina de los años noventa. Serie Financiamiento del Desarrollo, CEPAL, Volumen 135 
Della Paolera G, Taylor A (2001) Straining at the anchor: The Argentine currency board and the search for macroeconomic stability 1880-1935. The University of Chicago Press, Chicago

Di Tella G (1987) Argentina's most recent inflationary cycle, 1975-1987. In: Thorpand R, Whitehead L (eds) Latin American debt and the adjustment crisis. University of Pittsburgh Press, Pittsburgh, pp 162-207

Di Tella G, Dornbusch R (1983) The political economy of Argentina 1946-1983. University of Pittsburgh Press, Pittsburgh

Di Tella G, Zymelman M (1967) Las etapas del desarrollo económico Argentino. Editorial Universitaria de Buenos Aires, Buenos Aires

Di Tella G, Zymelman M (1973) Los ciclos económicos argentinos. Paidós, Buenos Aires

Diaz-Alejandro C (1970) Essays on the economic history of the Argentine Republic. Yale University Press, New Haven

Etchemendy S, Collier R (2007) Down but not out: union resurgence and segmented neocorporatism in Argentina (2003-2007). Politics Soc 35(3):363-401

Fallon P, Lucas R (2002) The impact of financial crises on labor markets, household incomes, and poverty: a review of evidence. World Bank Res Obs 17:21-45

FIEL (2002) Productividad, competitividad y empresas. FIEL, Buenos Aires

Fiszbein A, Galiani S (2003) Does inflation increase wage inequality? Some preliminary evidence from Argentina. The World Bank LAC Flagship Report, background paper

Frenkel R, Gonzalez Rozada M (2002) Argentina: macroeconomic behaviour, employment and income distribution in the 1990s. In: Vos R, Taylor L, de Barro RP (eds) Economic liberalization, distribution and poverty. Latin America in the 1990s. Edward Elgar, Cheltenham

Galbraith J, Spagnolo L, Pinto S (2006) The decline of pay inequality in Argentina and Brazil following the crises and retreat from the neo-liberal model. UTIP working paper 34, The University of Texas Inequality Project

Galiani S, Porto G (2008) Trends in tariff reforms and trends in the structure of wages. Working paper available at SSRN: http://ssrn.com/abstract=1083908. Accessed 15 Nov 2008

Galiani S, Sanguinetti P (2003) The impact of trade liberalization on wage inequality: evidence from Argentina. J Dev Econ 72(2):497-513

Galiani S, Heymann D, Dabus C, Thome F (2008) On the emergence of public education in land rich economies. J Dev Econ 86(2008):434-446

Gasparini L (2003) Different lives: inequality in Latin America and the Caribbean”, Chapter 2. In: De Ferranti D, Perry G, Ferreira F (eds) Inequality in Latin America and the Caribbean: breaking with history? The World Bank

Gasparini L (2005) Poverty and inequality in argentina: methodological issues and a literature review. CEDLAS and The World Bank, Mimeo

Gasparini L (2007) Monitoring the socioeconomic conditions in Argentina. CEDLAS and The World Bank, Mimeo

Gasparini L, Cruces G (2008) A distribution in motion: the case of Argentina, Documento de Trabajo CEDLAS N. 78, CEDLAS, UNLP, Argentina. In: LF López-Calva, N Lustig (eds) chapter 5 in Declining inequality in Latin America: a decade of progress? Brookings Institution Press, Washington, DC (ISBN 0-8157-0410-0, 2010)

Gasparini L, Cruces G (2010) Las Asignaciones Universales por Hijo: Impacto, Discusión y Alternativas. CEDLAS working paper 102

Gasparini L, Cruces G, Tornarolli L (2011) Recent trends in income inequality in Latin America. Economía 11(2):147-190 (journal of the Latin American and Caribbean Economic Association)

Goldberg P, Pavcnik N (2004) Trade, inequality, and poverty: what do we know? Evidence from recent trade liberalization episodes in developing Countries, Brookings Trade Forum, pp 223-269

Goldberg P, Pavcnik N (2007) Distributional effects of globalization in developing countries. J Econ Lit XLV(1):39-82

González M, Menéndez A (2000) The effect of unemployment on labor earnings inequality: Argentina in the Nineties. RPDS Working Papers 1/00, Princeton University

Halac M, Schmukler SL (2004) Distributional effects of crises: the financial channel. Economía 5(1):1-67 (Journal of the Latin American and Caribbean Economic Association)

Heymann D, Leijonhufvud A (1995) High inflation. Clarendon Press, Oxford

Hirschman A (1973) The changing tolerance for income inequality in the course of economic development. Quart J Econ 87:544-566 
Katz J (2000) Cambios en la estructura y comportamiento del aparato productivo latinoamericano en los años 1990. Serie Desarrollo Productivo 65 CEPAL, Santiago

Kosacoff B (1998) Business strategies under stabilization and trade openness in the 1990s. Documento de trabajo CEPAL, Buenos Aires

Krusell P, Ohanian L, Ríos-Rull J, Violante G (2000) Capital-skill complementarity and inequality: a macroeconomic analysis. Econometrica 68:1029-1053

Landais C (2007) High income in France (1998-2006): an explosion of inequalities. Paris School of Economics Working Paper

Lindenboim J, Graña J, Kennedy D (2005) Distribución funcional del ingreso en Argentina. Ayer y hoy, Cuaderno de Trabajo 4, Centro de Estudios sobre Población, Empleo y Desarrollo, Facultad de Ciencias Económicas, Universidad de Buenos Aires

Londoño J, Székely M (2000) Persistent poverty and excess inequality: Latin America, 1970-1995. J Appl Econ 3(1):93-134

Lustig N (2000) Crises and the poor: socially responsible macroeconomics. Economía 1(1):36 (Journal of the Latin American and Caribbean Economic Association)

Mallon RD, Sourrouille JV (1975) Economic policymaking in a conflict society. Harvard University Press, Cambridge

Marshall A (2002) Transformaciones en el empleo y la intervención sindical en la industria: efectos sobre la desigualdad de salarios. Desarro Econ 42(166):211-230

Marshall A (2005) Labor regulations and unionization trends: comparative analysis of Latin American countries, Cornell University, Visiting Fellow Working Papers

Murillo V (1997) La adaptación del sindicalismo argentino a las reformas de mercado en la primera presidencia de Menem. Desarro Econ 37(147):419-446

Navajas F (1999) El impacto distributivo de los cambios en precios relativos en la Argentina entre 1988-1998 y los efectos de las privatizaciones y la desregulación económica, Chapter IV. 4 in FIEL

Neffa J (2005) Las principales reformas de la relacion salarial operadas durante el periodo 1989-2001 con impactos directos o indirectos sobre el empleo. Materiales de Investigación no 4, CEIL-PIETTE/ CONICET (Centro de Estudios e Investigaciones Laborales, Programa de Tecnología, Investigaciones Económicas sobre Trabajo y Empleo), Buenos Aires, Argentina

Piketty T (2001) Les hauts revenus en France au 20ème siècle. Grasset, Paris

Piketty T (2003) Income inequality in France, 1901-1998. J Polit Econ 111:1004-1042

Piketty T (2006) The Kuznets curve: yesterday and tomorrow. In: Banerjee AB, Bénabou R, Mookherjeee D (eds) Understanding poverty, 4th edn. Oxford University Press, Oxford

Piketty T, Saez E (2003) Income Inequality in the United States, 1913-1998. Q J Econ 118(1):1-39

Piketty T, Saez E (2006) The evolution of top incomes: a historical and international perspective. Am Econ Rev 96(2):200-205

Piketty T, Saez E (2013) Optimal labor income taxation. In: Auerbach A, Chetty R, Feldstein M, Saez E (eds) Chap. 9 in Handbook of public economics, vol 5. Elsevier, North Holland

Rapoport M (1980) 1949-1945 Gran Bretaña, Estados Unidos y las Clases Dirigentes Argentinas. Editorial de Belgrano, Buenos Aires

Robinson J (2010) The political economy of redistributive policies. In: López-Calva L, Lustig N (eds) Declining inequality in Latin America: a decade of Progress?, chapter 3. The Brookings Institution, Washington, DC

Robinson J, Sokoloff K (2004) Historical roots of Latin American inequality. World Bank

Saez E, Veall M (2005) The evolution of high incomes in North America: lessons from Canadian Evidence. Am Econ Rev 95:831-849

Sturzenegger FA (1997) Understanding the welfare implications of currency substitution. J Econ Dyn Control 21(2):391-416

Székely M (2005) Pobreza y desigualdad en México entre 1950 y el 2004, Serie documentos de investigación 24, Secretaría de Desarrollo Social (SEDESOL), México

Taylor A (1992) External dependence, demographic burdens and Argentine economic decline after the belle epoque. J Econ History 52(4):907-936

Vazquez-Presedo V (1998) Estadísticas históricas argentinas: compendio 1873-1973. Instituto de economía aplicada, Buenos Aires

Williamson J (2009) History without Evidence: Latin American Inequality since 1491, NBER Working Paper No. 14766 